\title{
医学的リハビリテーションからみた 切断・脳卒中・脊䯣損傷患者の職場復帰の現状と課題*1
}

\begin{abstract}
田中宏太佳*2
Current Status and Issues of Return to Work in Amputees and Patients with Spinal Cord Injury and Stroke from the Viewpoint of Medical Rehabilitation*1
\end{abstract}

\author{
Hirotaka TANAKA*2
}

\begin{abstract}
More than $80 \%$ of amputee patients are able to return to work. Younger amputees were more likely to return to work. Poorly fitted artificial limbs and blue-collar worker status were disadvantageous factors. Devices such as the myoelectric hand and work arm are important for reinstatement of upper extremity amputees. Important factors for early return to work in stroke patients were job category, Barthel index at the onset, employment status and modified Rankin Score at discharge. Early return to work rate after discharge was $30 \%$. Factors related to the early return to work for stroke patients with light disability were intellectual, memory, and attention dysfunction. The return to work rate after 18 months for stroke patients was $51 \%$. Age, sex, urinary tract infection, spontaneous urination, motor scores of American Spinal Injury Association on admission, marital status and job category have all been associated with the return to work rate for spinal cord injury patients. Their early return to work rate was $13 \%$. (Jpn J Rehabil Med $2013 ; 50: 11-15)$
\end{abstract}

Key words : 切断 (amputation), 筋電義手 (myoelectric hand), 脳卒中 (stroke), 脊䯣損傷 (spinal cord injury), 職場復帰 (return to work)

はじめに

リハビリテーション（以下，リハ）医学が対象とす る患者には，機能障害や能力障害のみならず社会的不 利が生じる. 特に労働年齢に受傷した障害者において は，職場復帰が社会参加の重要な目標になる。それぞ れの障害ごとに, 職場復帰に関係する重要な因子やそ の現状は異なり，その課題も同様に相違する。今回 は，医学的リハに扔いて重要な対象疾患である，切 断, 脳卒中, 脊髄損傷において職場復帰の現状を調査 し，関係する因子を検討した。

\section{労働災害による切断患者の職場復帰}

労災 1 級から 5 級に相当する 377 名, 方法は横断的 なアンケート調查で行った ${ }^{1)}$. 結果は $43.2 \%$ の回収率 で, 労働年齢である 64 歳以下で就労状況の記載ある 127 名を分析の対象とした。男性は $89 \%$ で平均年齢 は 50.2 歳, 切断時平均年齢 32.3 歳であった. 復職者 の平均年齢は 48.8 歳, 非復職者の 56.5 歳は有意に高 齢であった。労災障害等級では，1 級で $60 \% ， 5$ 級で $92 \%$ の復職率，上肢切断 $83 \%$, 下肢切断 $81 \%$ と高率 に復職していた。

切断前の仕事（表 1）では，工場作業や建築作業の

2012 年 8 月 31 日受稿

*1 第 49 回日本リハビリテーション医学会学術集会シンポジウム「障害者の社会参加と職場復帰」(2012 年 5 月 31 日, 福岡）の講演をまとめたものである.

*2 中部労災病院リハビリテーション科/テ 455-8530 愛知県名古屋市港明 1-10-6

Chubu Rosai Hospital

E-mail : tanakahirochubu@yahoo.co.jp 
表 1 切断者の切断前の職業と復職率

\begin{tabular}{lrcc}
\hline \multicolumn{1}{c}{ 因子 } & 患者数 (名) & 復職率 $(\%)$ & $p$ \\
\hline 切断前の仕事 & & & \\
事務 & 5 & 80.0 & 0.805 \\
販売 & 3 & 100 & \\
農業漁業林業 & 2 & 50 & \\
サービス & 9 & 88.9 & \\
管理 & 3 & 100 & \\
医療 & 1 & 100 & \\
運輸 & 15 & 86.7 & \\
専門技術 & 9 & 77.8 & \\
工場作業 & 57 & 84.2 & \\
建設作業 & 13 & 69.2 & \\
\hline
\end{tabular}

ブルーワーカーの割合が多く，職種において復職の有 意差はみられなかったが，復職する場合においてはホ ワイトカラーに配置替えをして行う場合が多くみられ た。

断端の問題では，断端痛と幻肢痛が約半数の切断者 にみられた。復職に関係する有意な因子は示されな かったが，義肢が合わないという愁訴があると，復職 率は低下していた。

\section{作業用義手を使用した患者の職場復帰}

上肢切断患者が復職する場合，作業用義手を工夫す ることで原職に円滑に復職できた例を提示した ${ }^{2)}$ ．症 例 1 は調理師の 42 歳の男性で，食事運搬のコンベアー が空回りしたので修理をしていたところ，他の職員が 知らずにスイッチを入れたために右上肢を巻き込まれ て受傷した．労災病院で義手が製作された．能動義手 の他に，作業用義手として，食材によって菜切り包丁

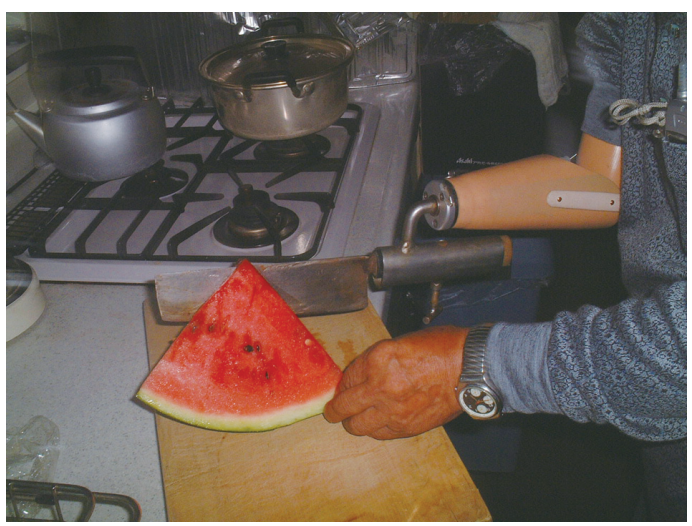

図 1 調理師に復職した切断者の作業用義手

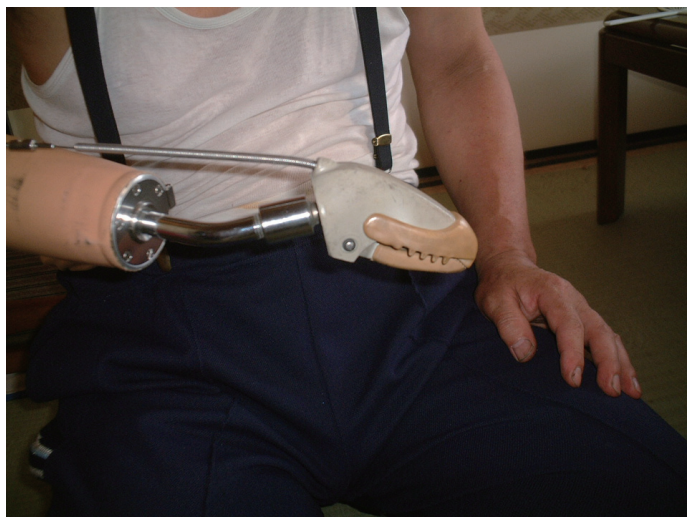

図 2 印刷作業員に復職した切断者の作業用義手

や刺身包丁などに簡単に差し替えられ，差し入れる角 度を選択できるようにしたものを作成した（図 1)。 また肘継ぎ手が破損しにくいようにねじで補強してい る。

症例 2 は印刷工の 50 歳男性である。印刷作業中, 機械に上肢を巻き込まれて受傷した。労災保険での本 義手を労災病院で製作した. 8 力後に復職した。作業 用義手として，印刷作業時に印刷の仕事にはアルミ板 を扱う過程があり，能動フックではアルミに傷をつけ るために子供用の能動ハンドを工夫しゴムを装着（図 2）して使用している。

\section{労災保険研究用支給筋電電動義手を 使用した患者の職場復帰}

上肢切断者には，筋電義手を作成することが復職に とって非常に有利であることを経験する，労災保険で は 2008 年 4 月から 1 上肢を手関節以上で失った切断 患者に対して，研究用支給が 3 年間実施され，2011 年 4 月から 2 年間支給期間が延長された。

中部労災病院は中部東海地区の指定医療機関として 3 年間で 14 名に研究用支給筋電義手を作成した ${ }^{3}$ （表 2). 前腕切断者が主体であるが，2名の手関節離断患 者にも作成しており，また 3 名の上腕切断患者にも筋 電義手を作成した。

筋電義手の活用状沉で，8名の原業就業者では積極 的使用 7 名・消極的使用 1 名， 6 名の事務職では積極 的使用 5 名・消極的使用 1 名であった. 1 名は失職し ていたが，筋電電動義義手装着後事務職として新規再 就職が可能となり，職場でも筋電電動義手を積極的に 
切断・脳卒中 · 脊髄損傷患者における職場復州の現状と課題

表 2 研究用支給筋電義手作成対象者

\begin{tabular}{|c|c|c|c|c|}
\hline 症例 & 年齢（歳） & 性別 & 断端 & 職業 \\
\hline 1 & 39 & 男 & 右前腕長断端（88\%） & エンジンの整備 \\
\hline 2 & 39 & 男 & 左前腕中断端（63\%） & 家電販売 ～～～～～～～～ \\
\hline 3 & 52 & 男 & 右手関節離断 & 鍛治屋（検品, リフト操作） \\
\hline 4 & 42 & 男 & 右前腕短断端（40％） & 生産管理，パソコン \\
\hline 5 & 36 & 男 & 右前腕短断端（50\%） & 事務職 ～～～～～～～～～ \\
\hline 6 & 46 & 男 & 右前腕短断端（44\%） & パソコン操作, 機械監視 \\
\hline 7 & 36 & 男 & 右手関節離断 & リサイクル物粉砕加工 \\
\hline 8 & 47 & 男 & 右前腕中断端（67\%） & 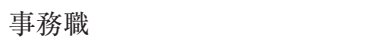 \\
\hline 9 & 48 & 男 & 右前腕長断端（93\%） & 元プレス工 (事務職に再就職) \\
\hline 10 & 67 & 男 & 右前腕中断端（62\%） & 不織布の製造販売 \\
\hline 11 & 52 & 男 & 右上腕切断標準（54\%） & 活性炭の製造 \\
\hline 12 & 61 & 男 & 左前腕短断端（50\%） & タクシー配車係 \\
\hline 13 & 68 & 男 & 左上腕切断標準 $(89 \%)$ & 鉄の加工処理 \\
\hline 14 & 21 & 男 & 右上腕切断標準（73\%） & 菓子の製造ライン \\
\hline
\end{tabular}

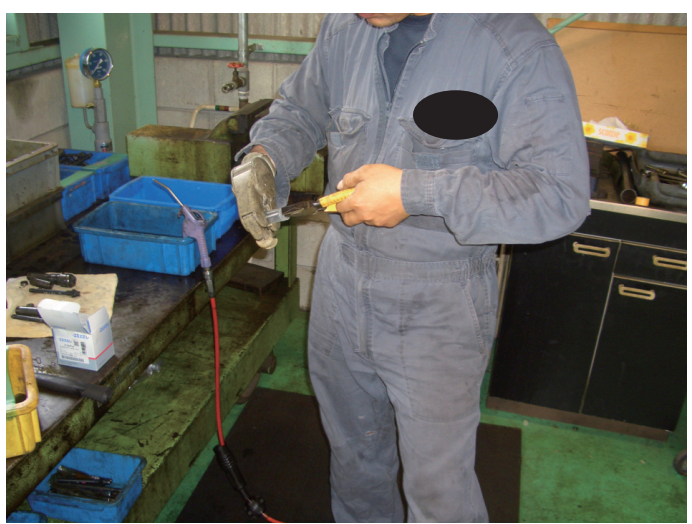

図 3 自動車工に復職した筋電義手グライファーの 操作

\section{使用していた。}

症例は右前腕切断の 39 歳男性である。職業は ディーゼルエンジンの整備で, 切断端は長断端で幻肢 が有る．機械ファンに巻き达まれて，手関節より切断 された。電気関係のパソコンや機械操作中心の業務に 復職した。仕事中装飾義手を装着していた。能動義手 は持っているがほとんど使用しなかったそうである. 仕事以外では, 義手は装着していなかった. 切断後 2 年 2 力月目に，筋電義手装着訓練を開始した。週 1 回 の通院で 7 週後に訓練を終了した. Dynamic Mode Control（DMC）グライファーを職場で使用した（図 3). 患者には, 仕事でネジやボルト操作を行う場合, 高所や低い位置でのしっかりとした把持力が必要とさ れている. 電動ハンドでは, 指の把持面が丸いために

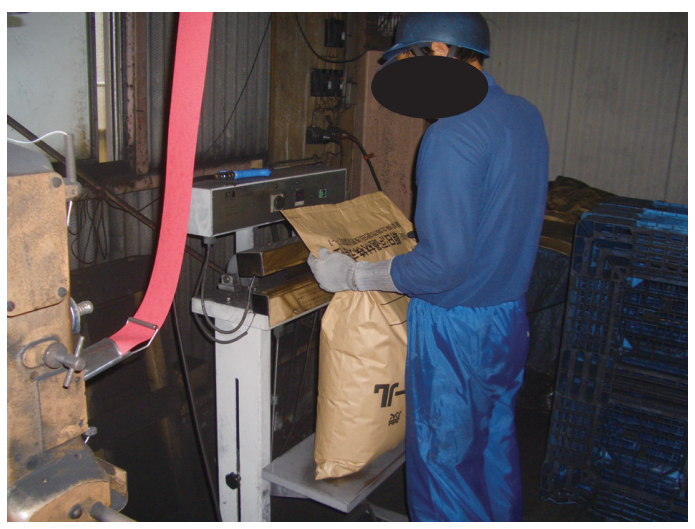

図 4 活性炭の製造工に復職した上腕切断患者の筋 電義手操作

ネジやナットなどが指先で滑ってしまうが，グライ ファーではネジ回し・レンチ作業においてピンチ・把 持操作が電動ハンドに比べて格段に良好である．把持 する面が平たく掴み易い。また面で持つことで安定的 に把持できた。

次の症例は, 右上腕切断の 52 歳男性である. 職業 は活性炭を袋に詰める作業，切断端は上腕は健側の $54 \%$ 断端長である。現病歴は, 活性炭を製造する 機械に右手を巻き込まれて受傷した。 上腕以遠の皮膚 欠損が重度なために当日切断術を受けた. 5 力月の能 動義手訓練の後に復職した.しかし，能動フックでは しっかり把持できない，袋をフックで破ってしまうな どの問題があり, 受傷 1 年後に筋電義手訓練を開始し た. 上腕筋での筋電分離を確認し, 労災保険研究用支 
給制度で認められた訓練期間 2 カ月の訓練を行うも成 果は不十分で，追加 1 カ月半の訓練を行うことが必要 であった。

上腕ソケットはオープンショルダー吸着式・ブロッ ク肘継手・前腕リフトアシスト・DMC 4 チャンネル 電動ハンドで作成した，筋電義手での復職後，活性炭 の入った袋を持ち運ぶ（図 4)，ボルトやナットを押 さえて行う作業，ミシンかけ，梯子段の昇降などが容 易となり満足度が高い．健康関連 QOL では 8 つの項 目で平均値を超えていた。

\section{脳卒中における職場復帰について (労災疾病等 13 分野医学研究「職場復帰のための リハビリテーション」分野の第 1 次データの分析より)}

脳卒中患者の退院早期および発症後 1 年半における 復職に影響する，身体機能障害のみでなく高次脳機能 障害や，産業保健領域での関連因子を検討した。

対象は，15歳から 64 歳までの労働年齢で，2005 年 2 月 1 日から 2006 年 7 月 31 日までに, 再発や一過性 脳虚血発作を除き新規に発症し全国 21 の労災病院で リ八治療を受けた症例である. Phase 1 及び Phase 2 の情報を収集できた症例は 464 名でこのうち就業者は 351 名であった。

方法は，入院時調查（Phase 1）項目は，業種職種, 既往歴などの一般的な属性，就業形態などの勤労状 況，脳卒中診断や機能障害や能力障害など。退院時調 查（Phase 2）項目は，退院日，高次脳機能障害なと の入院中の合併症, modified Rankin Score (mRS) な どの退院時の機能評価，退院時の雇用状況などの早期 職場復帰に関する情報である。発症後 1 年半後調查の 項目として，発症後の安否状況，職業状沉や復職に関 する医療機関の復職支援状況などを調査した ${ }^{4,5}$.

統計手法は, 退院早期の復職・非復職の観点から単
変量解析を行い，早期復職に関しては，多重ロジス ティック回帰分析を使用して分析した． 1 年半後の復 職率も提示した。

職種，発症時の Barthel Index（BI），退院時の雇用 状態, 退院時の mRS は多变量解析において脳卒中の 早期復職に関係する因子として示された。mRSが 2 以下の障害の軽い脳卒中に扔いては，注意障害・記憶 障害・知能障害が脳卒中の早期復職に関係する因子と して示された（表 3 )。また脳卒中発症後 18 力月後の 復職率は $51 \%$ であった。

\section{泰髄損傷における職場復帰}

目的は，外傷性脊䯣損傷患者の職業復帰に関係す る，医学的因子や生物学的要因だけでなく，特にどの ような社会的因子が職業復帰の可否に影響を与えるか について，脊髄損傷リハデータベースを使用して，多 施設の多数症例で検討することにした ${ }^{6)}$.

対象は，1997年から 2009 年までの 12 年間に, 27 のデー夕提供病院に発症から 1 年以内に入院し, 受傷 時に就労していた初回入院の外傷性脊髄損傷患者とし た。受傷時に 15 歳から 64 歳の労働年齢の患者, 無 職・学生・主婦であるものは除いた，最終的に 1680 名が対象となった。対象者の年齢分布は，20歳代と 50 歳代にピークのある 2 峰性となった.

結果：受傷時の職業は，技能労働・建築土木・専門 技術の順であった，受傷原因は，交通事故・転落・落 下物の下敷きの順であった。単変量解析の結果を参考 に検討項目を選択し，年齢・性・入院時 Functional Independence Measure（FIM）で調整すると 15 項目 （保険，結婚歴，受傷時職業，入院時麻瘏高位と程度， 痤縮，自律神経過反射，呼吸器感染症，尿路感染症， 尿路結石, 肝障害, 裖瘡, 排尿方法, 排便方法, ASIA 運動スコア，ASIA 触覚スコア）が脊髄損傷の退

表 3 軽度身体障害を持つ脳卒中患者の早期復職に関係する高次脳機 能障害 (文献 5 より引用)

\begin{tabular}{lccc}
\hline \multicolumn{1}{c}{ Variables } & Reference & Odds ratio & 95\% Confidence interval \\
\hline Aphasia & Yes vs No & 0.43 & $0.17-1.06$ \\
Visuospatial neglect & Yes vs No & 0.30 & $0.08-1.10$ \\
Attention dysfunction & Yes vs No & 0.35 & $0.14-0.91$ \\
Memory dysfunction & Yes vs No & 0.35 & $0.14-0.89$ \\
Intelligence dysfunction & Yes vs No & 0.32 & $0.12-0.89$ \\
\hline
\end{tabular}

Tanaka H, Toyonaga T, Hashimoto H. Arch Phys Med Rehabil 2011 
院後早期の職場復帰に関係する傾向があることがわ かった。

多重ロジスティック回帰分析で，最終的に受傷時職 業において，建築土木に比べて経営管理が 7 倍・専門 技術が 3 倍・事務が 4.2 倍などと復職しやすいことが わかった．排尿管理では，留置カテーテルに比べて自 然排尿が 4.8 倍・自己導尿が 4 倍，尿路感染症が有る 者に比べて無い者が 1.8 倍, 結婚歴や入院時 American Spinal Injury Association（ASIA）運動スコアおよ び，調整因子として使用した年齢の若いほうが，性別 では男性の方が早期の職場復帰が行いやすいことが示 された。

\section{おわりに}

切断患者の職場復帰において, 上肢下肢切断者と も，80\%以上の割合で職場復帰が行えていた。切断 患者の復職においては，切断時および現在の年齢の若 い方が有利であることが伺えた．また，障害等級が重 度，断端の問題で義肢適合が不良，建築などのブルー ワーカー職種の復職が難しい傾向が見られた。 上肢切 断者においては，作業用義手や筋電義手などの工夫を 行うことが，復職を促進することが推測された。

脳卒中患者の職場復帰において, 早期復職に関係す る因子は, 職種, 発症時の BI, 退院時の雇用状態, 退院時の mRS であった. 労災病院退院後早期の復職 率は $30 \%$ で，障害の軽い脳卒中患者の早期復職に関 係する因子は, 注意障害・記憶障害・知能障害であっ た. 脳卒中患者の 18 力月後の復職率は $51 \%$ あっった. 脊髄損傷患者の職場復帰において，早期に職場復帰 しやすい条件として，(1）年齢が若い，（2）男性, （3）尿路感染症が無い，（4）自然排尿が可能，（5）入 院時 ASIA 運動得点が高い，（6）結婚歴，（7）受傷時 職業は経営管理や事務などのいわゆるホワイトカラー 職種が建築土木などのブルーカラー職種よりも復職し

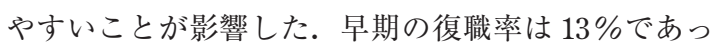
た。

労災疾病「職場復帰のためのリハビリテーション」分野 (脳卒中) に関する研究者は, 主任研究者：豊永敏宏（九 州労災病院). 分担研究者: 住田幹男 (愛仁会リ八病院), 豊田章宏 (中国労災病院), 富永俊克 (山口労災病院), 田 中宏太佳 (中部労災病院), 河津隆三 (九州労災病院). 共 同研究者：徳弘昭博（吉備高原医療リハビリテーションセ
ンター), 佐伯覚（産業医科大学若松病院）

脳卒中調査症例提供施設は, 九州労災病院, 中部労災病 院, 山口労災病院, 東京労災病院, 関西労災病院, 中国労 災病院, 吉備高原医療リハビリテーションセンター, 関東 労災病院, 富山労災病院, 門司メディカルセンター, 大阪 労災病院, 釧路労災病院, 長崎労災病院, 岡山労災病院, 熊本労災病院, 愛媛労災病院, 燕労災病院, 浜松労災病 院, 和歌山労災病院, 香川労災病院, 千葉労災病院, 以上 21 病院である.

脊髄損傷データベースを使用するにあたり，全国脊髄損 傷データベース管理運営委員会 (代表: 住田幹男), およ び日本リハビリテーション医学会データマネジメント特別 委員会 (委員長 : 近藤克則) の許可を得た. 脊髄損傷デー タベースのデータシート作成等にあたり, 平成 23 年度厚 生労働科学研究「全国リハビリテーション患者データベー スを用いた維持期障害者に対する効果的な社会復帰支援に 関する研究」(研究代表者：菊地尚久）の支援を得た.

継続して脊髄損傷のデータ提供が行われている病院は, 神奈川リハビリテーション病院, 吉備高原医療リハビリ テーションセンター, 熊本労災病院, 九州労災病院, 愛媛 労災病院, 山口労災病院, 中国労災病院, 山㓌労災病院, 関西労災病院, 大阪労災病院, 鹿島労災病院, 中部労災病 院，北海道中央労災病院せき損センターである.

\section{文 献}

1）田中宏太佳, 蜂須賀研二, 緒方 甫, 伊地知正光: 労働災 害による切断者の職業復帰に関する研究. 産業医学 ジャーナル $1995 ; 18: 77-81$

2) 田中宏太佳 : 切断者の職業復帰. 日本職業 - 災害医学会 会誌 $2003 ; 51: 197-201$

3）田中宏太佳, 中村恵一, 川村享平, 渡邊 真, 野本 葵, 宮川拓也, 溝手雅之, 林満, 松本芳樹: 労災保険研究 用支給制度を使用して中部労災病院で処方された筋電 電動義手使用者の復職状況とQOLについて : 3 年目の 中間報告. 第 27 回日本義肢装具学会学術集会 $2011 ; 85$ (抄)

4）豊永敏宏 : 職業復帰のためのリハビリテーション一脳 血管障害者の退院時における職場復帰可否の要因一。 日本職業・災害医学会会誌 $2008 ; 56: 135-145$

5) Tanaka H, Toyonaga T, Hashimoto $H$ : Functionaland occupational characteristics associated with very early return to work after stroke in Japan. Arch Phys Med Rehabil $2011 ; 92: 743-748$

6）田中宏太佳 : 外傷性脊髄損傷患者の職業復帰に関係す る因子についての検討 : 日本リハビリテーション医学 会リハビリテーション患者春髄損傷データベース 3688 名の分析. (研究代表者 菊池尚久: 厚生労働科学研究 費補助金「全国リハビリテーション患者データベース を用いた維持期障害者に対する効果的な社会復帰支援 に関する研究」) 報告書. 2012: 103-110 


\title{
《原 著》 ～シンポジウム○障害者の社会参加と職場復帰
}

\section{障害者の社会参加に関する評価*1}

\author{
増田公香 $* 2$
}

\section{Assessment of Social Participation for Persons with Disabilities*2}

\author{
Kimika Masuda ${ }^{* 2}$
}

\begin{abstract}
The aim of this article is as follows : 1) to introduce the scale of participation (participation restrictions) for the International Classification of Functioning, Disability and Health (ICF) , 2) to examine the results of a study of people with disabilities by using the Community Integration Questionnaire (CIQ), and 3) to identify the recent study in regard to the scale of participation (participation restrictions) in the ICF. In the 1990s, the Craig Handicap Assessment and Reporting Technique (CHART) and the CIQ were developed as scales to evaluate patients according to the International Classification of Impairments, Disabilities and Handicap (ICIDH). After 2000, CHART and CIQ has been adequate to assess the level of participation (participation restriction) of ICF. In this article, I examined the results of a study that conducted surveys of people with physical disabilities by using the CIQ. Finally, I examine the recent trend regarding the scale that was developed to closely parallel participation (participation restrictions) in the ICF.

(Jpn J Rehabil Med 2013; 50：16-20)
\end{abstract}

Key words : 参加 (participation), 参加制約 (participation restriction), 国際生活機能分類 (International Classification of Functioning, Disability and Health : ICF), 評価 (assessment)，スケール (scale)

\section{はじめに}

2005 年に成立した障害者自立支援法により，障害 を持つ人々の就労及び地域移行が推進され同時に社会 参加が強化されてきている.

世界保健機関（WHO）が規定した前障害概念の国 際障害分類試案（International Classification of Impairments, Disabilities and Handicaps：ICIDH）の社会的 不利に関しては，抽象的概念であるため従来その評価 は困難とされてきた。しかしながら 1990 年代に入り 海外を中心に様々な評価スケールが開発されてきた。 その中でも，代表的なものとして Craig Handicap Assessment and Reporting Technique (CHART) と Community Integration Questionnaire（CIQ）が挙げ
られよう。

CHART は，アメリカコロラド州のクレッグ病院の Gale Whiteneck 氏らにより 1992 年に開発された ${ }^{1}$ 。 当初 ICIDH の社会的不利として定義される 6 領域の うちの 5 領域を測定するものとして開発された。各領 域は 100 点満点で評価を行う。その後 1996 年に CHART は改定され（R-CHART），6領域により構成 されることとなった，CIQ は，外傷性脳損傷（Traumatic Brain Injury：TBI）の社会的不利の状況，こと に社会参加（特に社会統合）を評価するものとして Willer らにより開発された ${ }^{2}$.

その後 2000 年 5 月に WHO は新たな障害概念とし て国際生活機能分類（International Classification of Functioning, Disability and Health：ICF）を発表した.

2012 年 9 月 3 日受稿

*1 本稿は第 49 回日本リハビリテーション医学会学術集会シンポジウム「障害者の社会参加と職場復帰」(2012 年 5 月

31 日，福岡）の講演をまとめたものである.

*2 日本赤十字九州国際看護大学/干福岡県宗像市アスティ 1-1

The Japanese Red Cross Kyushu International College of Nursing

E-mail : k-masuda@jrckicn.ac.jp 
ICF において, 社会的不利は参加（参加制約）と変化 した、そのような動向の中, CHART と CIQ は参加 (参加制約）の評価スケールとしても適切であると支 持された ${ }^{3,4)}$.

本稿では, CHARTや CIQ という評価スケールの概 要を踏まえた上で, 筆者が行った研究結果を提示し参 加に関しての分析を行う。その上で，近年の参加（参 加制約）の動向について概観し，今後必要とされる課 題について検討する.

\section{参加（参加制約）の評価スケールの紹介}

CHARTは，(1)身体的自立 (Physical independence)， (2)移動（Mobility)，(3)時間の過ごし方 (Occupation), (4)社会的統合 (Social integration), (5)経済的自立 (Economic self-sufficiency) の 5 次元を測定するものと して開発された．各領域は， $0 \sim 100$ 点で合計 500 点 満点で評価される。体においては, 問川らにより 日本語版が作成された ${ }^{5)}$. その後, 1996 年に前述の 5 領域に認知的自立を加え 6 領域を評価する Revised CHART（R-CHART）が開発され，日本語版も作成さ れた ${ }^{6}$.

$\mathrm{CIQ}$ は, 15 項目の質問項目から構成されており， (1)家庭統合 (Home integration), (2)社会統合（Social integration), (3)生産統合 (Productivity) の 3 つのサ ブスケールに区分されている。家庭統合に関しては家 事・買い物について, 社会統合に関してはレジャー活 動・友人訪問等について, 生産統合に関しては就労・ 就学・ボランティア活動等について質問する. 評価得 点は, $0 \sim 29$ 点で評価され, 得点が高いほど社会参 加の度合いが高い.

CIQ 日本語版に関しては，筆者が 2001 年に原著者 であるWiller 氏より承諾を得て翻訳をし日本語版を 作成した ${ }^{7}$. CIQ は, 当初 TBI の社会参加 (社会統合) を評価するものとして開発されたが，他の障害の社会 参加の評価としても有効であるとされている.

\section{研 究 報 告}

\section{1. 肢体不自由障害を持つ人々の参加の実態把握注1) \\ 1) 研究内容}

本研究は，身体障害者手帳を保持し肢体不自由障害 を持ち地域に在住している人々の参加の実態把握を行 うことをその目的とした。サンプリングに関しては承 諾が得られた障害者団体に依頼した。

\section{2）研究方法}

（1）調査対象・調查時期：身体障害者手帳を保持し 地域に在住している 30 歳以上の人々を対象とした. 具体的には, 脳性麻痺 500 名・脊髄損傷 1,000 名・ポ リオ 1,000 名・リウマチ 700 名, 合計 3,200 名を対象 とした。調查実施時期は，2001年 11 月 1 ～ 30 日と した。

（2）調查内容：調査内容としては，基本的属性に関 しては, (1)性別, (2)年齢, (3)障害種類, (4)受障年齢, (5)教育，(6)結婚状況等を質問項目に入れた。常生活 動作（ADL）レベルに関しては機能的自立度評価法 （FIM）を用いた。また参加に関しては，CIQを用い た.

（3）調查方法：郵送による自己記入式アンケート調 查とした。ただし，障害により本人が自己記入できな い場合は，家族あるいは介護者に代理記入をしても らった。

（4）分析方法：参加の要因分析に関しては, 独立変 数に性別 - 年齢 - 受障年齢 - 結婚状況 - 学歴 - FIM スコアを投入し, 従属変数に $\mathrm{CIQ}$ 得点を投入し, 強 制投入法による重回帰分析を行った.

\section{3）研究結果}

1,653 名から有効回答が得られた（回収率 $51.6 \%$ ). 年齢に関しては, 最低年齢 30 歳, 最高年齢 87 歳, 平 均年齢 $54.4 \pm 13.6$ 歳であった。障害種類別にみる参加 の状況は図 1 に, 参加の性別による差異は図 2 に, 参 加の要因分析に関しては図 3 の結果となった ${ }^{8)}$.

\section{4) 考察}

障害種類別に参加の状況を検討した結果，脳性麻痺 のある人々が他の障害と比較しかなり低い事実が明ら かとなった．また，性差で検討した場合，参加に関し ては女性のほうがかなり参加のレベルが高いことが確 認された。参加の要因分析に関しては, FIM スコア すなわち ADL レベルに加え性別・年齢・受障年齢に 加え学歴が影響していることが確認された。これは, CHARTを用いたAnderson やWhiteneckら ${ }^{3,4)}$ の研究 でも同様のことが指摘されており, 参加の促進要因と して就学の環境整備の必要性が重要であるといえよ う. 
増田公香

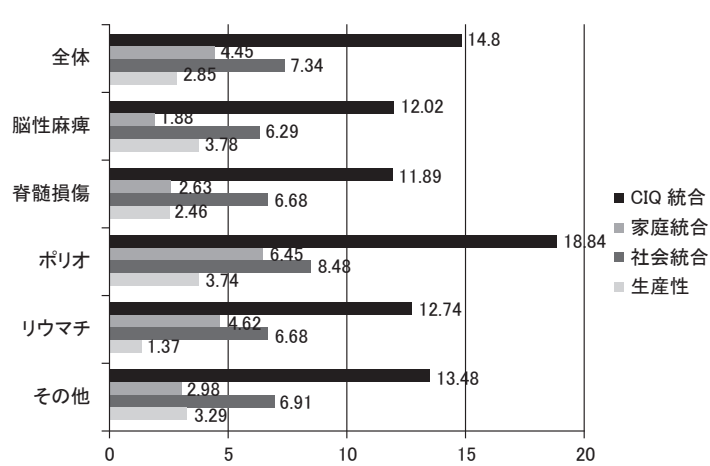

図 1 障害種類別にみる $\mathrm{CIQ}$ 得点 $(N=1,653)$

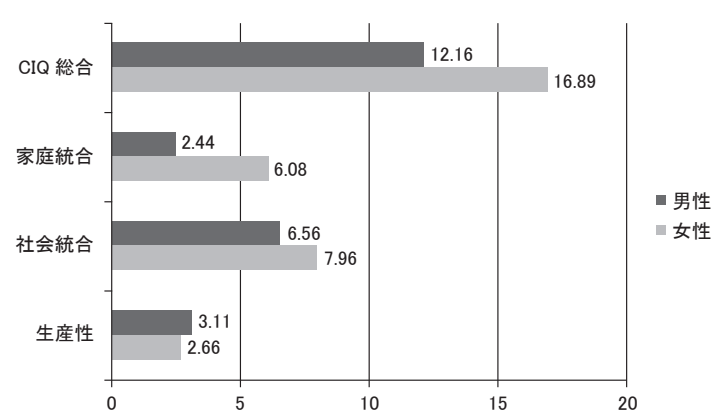

図 $2 \mathrm{CIQ}$ 得点の性差 $(N=1,653)$

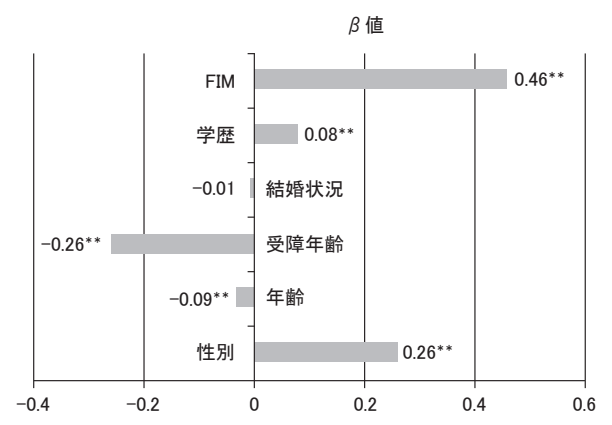

図 3 CIQ 総合得点要因分析（重回帰分析 $\beta$ 值） $(N=1,653)$

2. 肢体不自由障害を持つ人々と健常者との参加の 比較注1)

\section{1）研究内容}

本研究は，2002 年に障害を持たない健常者に対し て参加の実態把握を行い，2001年に実施した肢体不 自由障害を持つ人々に対して実施した参加の研究との 比較検討を行った.

\section{2) 研究方法}

（1）調査対象・調査時期：2002 年には障害を持た ない30 歳以上の健常者を対象に参加の実態把握を

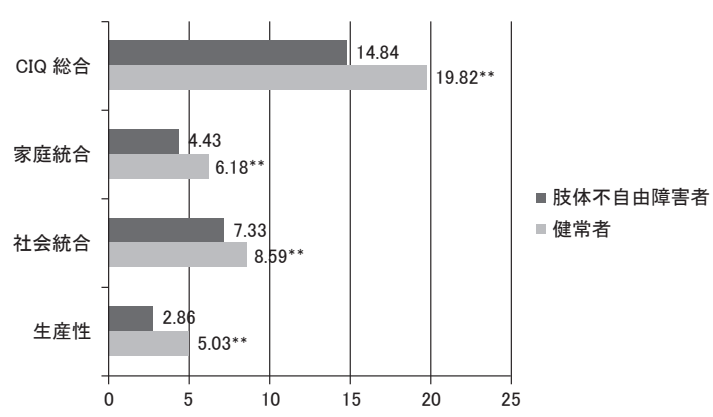

図 4 肢体不自由障害者と健常者との CIQ 得点の比較

行った。調査実施時期は，2002 年 11 月 1 日〜 30 日 とした。

（2）調査内容：2001年に実施した肢体不自由障害 を持つ人々の参加の実態把握と同じ質問内容で実施し た。

（3）調査方法：郵送による自己記入式アンケート調 査とした。

（4）分析方法： $\mathrm{t}$ 検定を行った.

3) 研究結果

参加に関する結果は，図 4 に示すとおりである。す べての項目において健常者が高かった.

\section{4) 考察}

肢体不自由障害のある人々と健常者とを比較した場 合，やはり健常者のほうが参加の程度は高かった。社 会統合に関しては，有意差は確認されたもののあまり 差異がみられなかったのに対し，生産性に関しては得 点においてかなりの差異がみられた点に注視すべきで あると考える。

\section{3. 障害の特性別にみる参加の相違 注2) \\ 1）研究内容}

本研究は， 2003 年度・ 2004 年度・ 2005 年度の 3 力 年にわたり障害のある人々に対し，身体障害・知的障 害・精神障害という障害種類別に参加と環境の実態把 握を行った. ここでは，参加の結果に焦点を当て，障 害の特性別に参加の相違について検討する。

\section{2) 研究方法}

（1）調査対象・調査時期：まず，身体障害のある 人々に関しては, 脊髄損傷障害を持つ人々 3,600 名を 対象に実施した。調査実施時期は，2004 年 1 月 20 日〜2月 20 日とした。

知的障害のある人々に関しては，1,000 名を対象に 実施した。調査実施時期は，2005 年 1 月 20 日〜 2 月 
28 日までとした。

精神障害のある人々に関しては，1,860 名を対象に 実施した。調查実施時期は，2006 年 1 月 20 日〜 2 月 28 日とした。

（2）調査内容：基本的属性と参加に関しては CIQ を用いた。

（3）調査方法：郵送による，自己記入式アンケート とした，ただし，障害により本人が自己記入できない 場合は，家族あるいは介護者に代理記入をしてもらっ た。

\section{3）研究結果}

脊髄損傷障害者に関しては，1,436 名から有効回答 が得られた（有効回答率 $39.9 \%$ )。知的障害者に関し ては，310名から有効回答が得られた（有効回答率 $31.0 \%$ ）。精神障害者に関しては，891名から有効回 答が得られた（有効回答率 $47.9 \%$ )。参加の結果に関 しては，図 5 に示すとおりである.

\section{4) 考 察}

障害種別に参加の相違を検討した結果, CIQ の総合 得点としては, 精神障害者が最も高かった。これはや はり $\mathrm{ADL}$ の自立度が高いことが要因として考えられ る.しかしながら, 社会統合に関しては, 脊髄損傷障 害者が最も高かった。人間関係を不得手とする精神障 害の特性が影響していると推察される．また生産活動 レベルの差異に関しては，受障後の経済的保障等の環 境の相違が影響していると考えられる.

\section{考察}

CIQ は開発から 20 年が経過するが，依然参加ある いは社会統合（social integration）の評価スケールと して現在でも多くの研究に用いられている年14). CIQ の特徵として, 質問項目が 15 項目と比較的質問項目 数が少なく平易な質問内容である点が長所として挙げ られよう。家庭統合のサブスケールに関しては，家事 への従事という事象の把握に留まらず，退院後の家庭 生活において家事に従事することを生活の中における リハビリテーション（以下，リハ）の一環として位置 付けることも重要ではないかと思われる，また，脳卒 中等脳血管障害でライフステージの中年期あるいは高 齢期に受障し障害を持つこととなる高齢障害者が増加 する中で, 就労及び生産活動には限界がある.今後は このような状況を鑑み, アンペイドな生産活動等の機 会の構築が重視される必要があると考える.

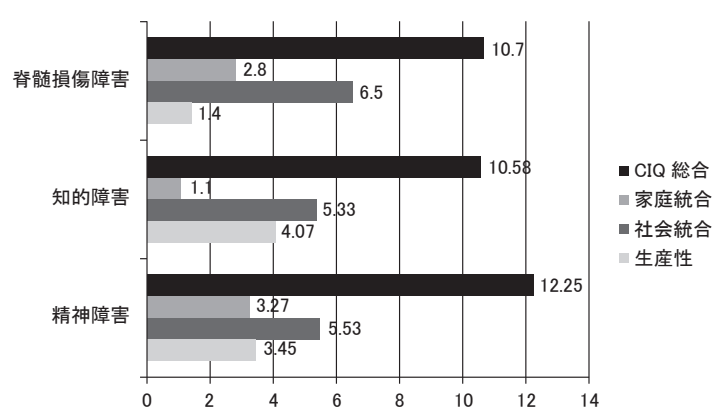

図 5 障害の特性別にみる CIQ 得点

CHART や R-CHART また CIQ は，社会参加（社会 統合）の評価スケールとして多くの研究に用いられて きた。しかしながら，当初 ICIDH の社会的不利の評 価スケールとして開発されたため ICF の参加（参加 制約）の評価スケールとしての限界性が議論されるよ うになってきた。また，参加に関しては，当事者の主 観的視点も重要視されるようになってきた。佐伯や蜂 須賀も社会参加が QOL の維持向上に強く影響してい ることを指摘している ${ }^{14)}$ 。このような背景の下，近年 ICF の参加（参加制約）に即した評価スケールとして 次のような新たな評価スケールが海外を中心に開発さ れてきている。具体的には, Brown らが POPS (Participation Objective, Participation subjective) ${ }^{15)}$ を, Ciceroneらが QCIQ（Quality of Community Integration Questionnaire) ${ }^{16)}$ を開発している。これらの評価 スケールは，参加（参加制約）を客観的に評価するだ けに留まらず，当事者の主観的視点をも評価の視野に 入れている点にその特徵がみられる.

\section{結 語}

障害のある人々にとり社会参加とは自己実現の基盤 であると考える。また高齢化が進展し高齢障害者が増 加する中で, 就労あるいは生産活動に代替するボラン ティア活動等の機会を増やすことは喫緊の課題である と思われる. その上で, 今後は当事者の主観的部分も 視野に入れた社会参加の評価が重視され，リ八医学・ 保健・福祉の連携の下での支援の展開が必要になると 考える.

注 1）平成 $13 \cdot 14$ 年度科学研究費若手研究（B）「加齢 する肢体不自由者の社会参加に関する学際的研究：課題番 号 13710122 (代表研究者 増田公香)」の一部として実施 した. 
注 2) 平成 $15 \sim 17$ 年度日本学術振興会科学研究費基盤 研究 (C)「加齢する障害を持つ人々の参加と環境との関連 性に関する研究：課題番号 15530378 (代表研究者 増田 公香)」の一部として実施した.

\section{文献}

1) Whiteneck GG, Cahrlifue SW, Gerhart KA, et al : Quantifying handicap : a new measure of long-term rehabilitation outcomes. Arch Phys Med Rehabil 1992 ; 73 : 519 526

2) Willer B, Rosentbal M, Kreutzer JS : Assessment of community integration following rehabilitation for traumatic brain injury. J Head Trauma Rehabil 1993 ; 8 : 75-87

3) Anderson CJ, Krajci KA, Vogel LC : Community integration among adults with spinal cord injuries sustained as children or adolescents. Dev Med Child Neurol 2003 ; 45 : 129-134

4) Whiteneck G, Tate D, Charlifue S : Predicting community reintegration after spinal cord injury from demographic and injury characteristics. Arch Phys Med Rehabil 1999 ; 80 : 1485-1491

5）問川博之, 高橋秀寿, 里宇明元, 千野直一 : CHARTによ る脳卒中患者の社会的不利の測定. 総合リハビリテー ション $1998 ; 26: 985-989$

6）熊本圭吾, 岩谷 力, 飛松好子, 熊野宏昭, 園田啓示, 外 里富佐江 : CHART日本語版の作成. 総合リハビリテー ション $2002 ; 30: 249-256$

7）増田公香, 多々良紀夫 : CIQ日本語版ガイドブック. KM 研究所, 埼玉, 2006

8）増田公香 : 加齢する肢体不自由障害を持つ人々の参加 の要因分析一障害種類別にみる特性に焦点をおいて一。 社会福祉学 $2004 ; 45: 35-45$
9) McVeigh SA, Hitzig SL, Craven BC : Influence of sport participation on community integration and quality of life : a comparison between sport participants and nonsport participants with spinal cord injury. J Spinal Cord Med 2009 ; 32 : 115-124

10) Dash AT, Braden A L, Craggs JG, Jensen MP : Psychometric properties of the community integration questionnaire in a heterogeneous sample of adults with physical disabilities. Arch Phys Med Rehabil 2011 ; 92 : 1602-1610

11) Burstein GJ, van Heugten CM, Martina JD, Reitveld AC, Meijer R, Geurts AC : Three-year follow-up results of a residential community reintegration program for patients with chronic acquired brain injury. Arch Phys Med Rehabil 2012 ; 93 : 908-911

12) William G, Wilmot $\mathrm{C}$ : Higher levels of mobility are associated with greater societal participation and better quality-of-life. Brain Inj 2012 ; 26 : 1065-1071

13) McLean AM, Jarus T, Hubley AM, Jongbloed L : Differences in social participation between individuals who do and do not attend brain injury drop-in centers : a preliminary study. Brain Inj $2012 ; 26: 83-94$

14）佐伯 覚, 蜂須賀研二: ポリオ罹患者の社会参加とQOL との関連. 日本職業・災害医学会会誌 $2011 ; 59: 73-77$

15) Brown M, Dijikers MP, Gordon WA, Ashman T, Charatz $\mathrm{H}$, Cheng $\mathrm{Z}$ : Participation objective, participation subjective : A measue of participation combing outsider and insider perspectives. J Head Trauma Rehabil 2004 ; 19 : 459-481

16) Cicerone KD, Mott T, Azulay J, Friel JC : Community integration and satisfaction with functioning after intensive cognitive rehabilitation for traumatic brain injury. Arch Phys Med Rehabil 2004 ; 85 : 943-950 


\title{
産業医学からのアプローチ*1
}

\author{
佐 伯 覚*2
}

\section{Occupational Medicine Viewpoint on Return to Work for the Challenged*1}

\author{
Satoru SAEKI ${ }^{* 2}$
}

\begin{abstract}
Promoting employment for physically challenged or handicapped persons is an important social responsibility strategy for the enterprise. This is true because there are employment quotas and levy and grant systems under the law for employment promotion of handicapped persons. However, from the rehabilitation view point, return to work (RTW) means reinstatement or re-employment of the handicapped persons, and RTW in occupational health only means changing jobs within the same company. This is due to the different methodology and basic laws in each field. Fitness for work, medical examination and the support system for RTW of handicapped persons in the company are important, and cooperation between occupational health and rehabilitation medicine is necessary. Occupational physicians or the RTW coordinator should be the key person for promoting RTW of the handicapped persons. (Jpn J Rehabil Med 2013; $50: 21-24)$
\end{abstract}

Key words : 産業医学 (occupational medicine), 職場復㷌（return to work）, 産業医 (occupational health physician), 適正配置（fitness for work)，連携（cooperation）

\section{はじめに}

図 1 は，わが国の脳卒中障害者の累積復職率を発症 からの経過日数で表したものである ${ }^{1)}$ 発症からの累 積復職成功率は一定のスピードで増加するのではな く, 発症 6 カ月までには比較的障害の軽度な患者が 復職する 1 番目の増加が認められる. 続いて発症後 1 年〜 1 年 6 カ月には, 中等度から重度障害の患者が 復職する 2 番目の大きな増加が認められ，その後プラ トーに達する。発症 1 年 6 力月は傷病手当金の受給期 限であり，休職期間の满了，換言すれば同一事業所内 での復職の最終期限でもある。すなわち，障害者の復 職には障害の種類や程度だけでなく, 復職・休職に関 連したシステムが大きく影響することをこのグラフは 示している.
筆者はリハビリテーション（以下，リハ）科専門医 になる前に産業医の経験を積んだが，リハと産業保健

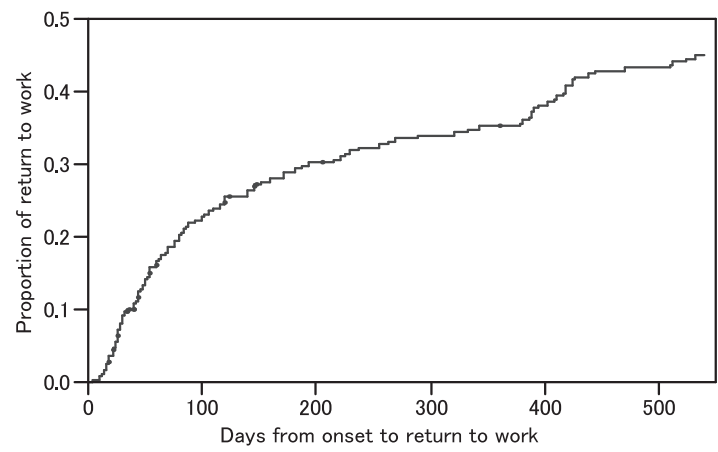

図 1 脳卒中後の復職率の推移（文献 1 より許可を得 て転載)

2012 年 7 月 2 日受稿

*1 第 49 回日本リハビリテーション医学会学術集会シンポジウム「障害者の社会参加と職場復帰」(2012 年 5 月 31 日, 福岡）の講演をまとめたものである。

*2 産業医科大学若松病院リハビリテーション科/T 808-0024 福岡県北九州市若松区浜町 1-17-1

Department of Rehabilitation Medicine, Wakamatsu Hospital of the University of Occupational and Environmental Health E-mail : sae@med.uoeh-u.ac.jp 
の両分野で，障害者の復職に対する考え方の違いを大 きく実感した ${ }^{2,3)}$. この考え方の違いを理解していな いと「ボタンの掛け違い」が生じ障害者の復職を阻害 することがある．この違いの根底には産業保健分野独 自の考え方やシステムがある。本シンポジウムでは, 障害者の復職において，企業の適正配置の考え方，復 職健診システムや復職支援システムについて述べた w.

\section{産業医学における復職}

障害者の復職の意義と課題は表 1 のとおりである. リハの観点からは，社会復帰や経済的自立を主に考え るが，産業保健の観点からは適正配置や職場適応が重 視されている $(\text { 表 } 1)^{4,5)}$. 企業にとって障害者雇用の 問題は，企業の社会的責任として重要な戦略の 1 つに なっている。その背景に「障害者の雇用の促進等に関 する法律」で定められた法定雇用率，雇用納付金によ るペナルティ制度があることは否めない（表 2).

リハの観点からは「転職を含む幅広い就労への復 帰」を復職（職業復帰）と捉えることが多いが，産業 医学の分野では「同一企業内の配置転換を含む復帰」 を復職（職場復帰）と捉えている（図 2)。その違い は英語表記にも表れており，狭義の復職である職場復 帰は，広義の復職である職業復帰に含まれる概念であ る.

この復職の捉え方の違いは，それぞれの分野の方法 論の違い，具体的には根拠としている法律が異なるこ

表 1 障害者の復職の意義と課題

・社会復帰の一形態 (Quality of working life)

・経済的自立 (Tax payer)

- 適正配置（Fitness for work）

·職場適応 (Workplace accommodation)

表 2 障害者の雇用に関する施策

・障害者基本法・障害者雇用促進法

ノーマライゼイションの理念の実現

障害者雇用は企業の社会的責任

·事業主に対する指導・援助

法定雇用率・納付金制度

- 職業リハの実施

職安・障害者職業センター

・重度化に対応した雇用の場の確保

第 3 セクター方式による企業の設立（特例子会社）

下線部は特に産業保健分野に影響が大きい事項
とにも起因している。すなわち，リハの立場からは， 「復職は社会復帰の一形態であり，仕事をすることは 権利であり生きがいである」と解される，一方，産業 保健分野では「作業は人体に対する一種の負荷であ り，傷病や障害は人間の能力を可逆的あるいは不可逆 的に低下させる. 人間の能力が作業負荷と一致するよ う管理すること，すなわちリスクコントロールするこ とが，適正配置としての復職である」とされる $。$.表 3 に各々が関係する法規をあげたが，リハ関係では社 会復帰の側面が強いのに対して, 産業保健関係では労 働における安全衛生が重視されている。産業保健にお ける安全衛生は，表 4 に示す「法令による病者の就業 禁止」に如実に現れている．障害者は必ずしも病者と は限らないが，企業においては安全衛生の観点から 「法令による病者の就業禁止」に準じた対応がなされ ているのが現状である。

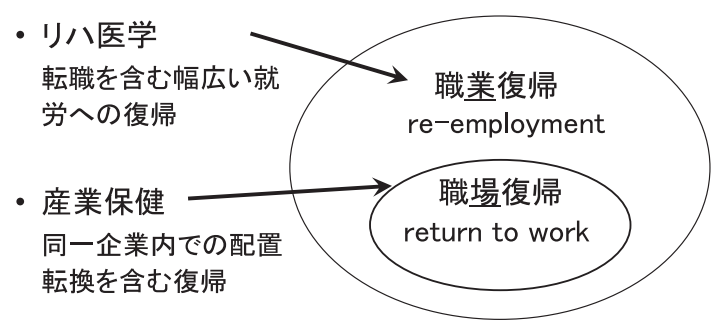

図 2 復職とは?

表 3 復職に関わる法規

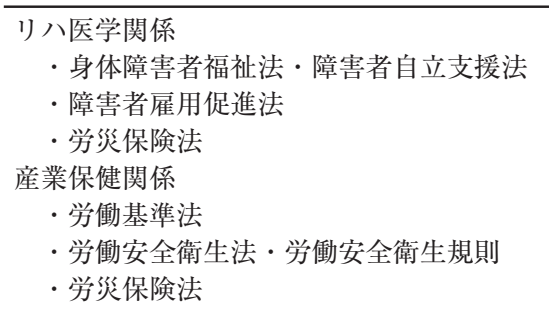

表 4 法令による病者の就業禁止

全労働者を対象とした法令

- 労働安全衛生法 (第 68 条)

·労働安全衛生規則 (第 61 条)

特定の労働者を対象とした法令

・鉛中毒予防規則

・四アルキル鉛中毒予防規則

·高気圧作業安全衛生規則

・電離放射線障害防止規則 


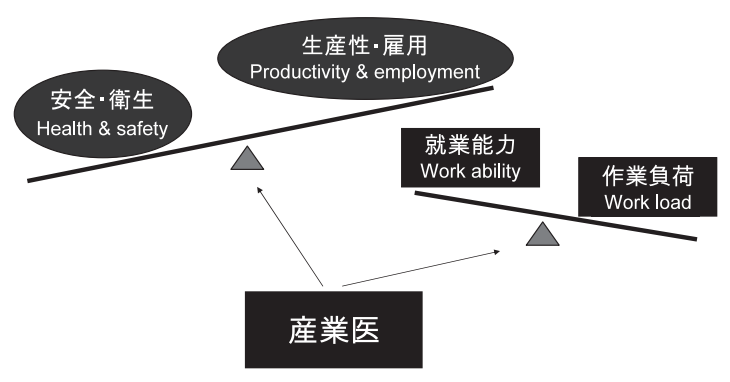

図 3 適正配置の考え方

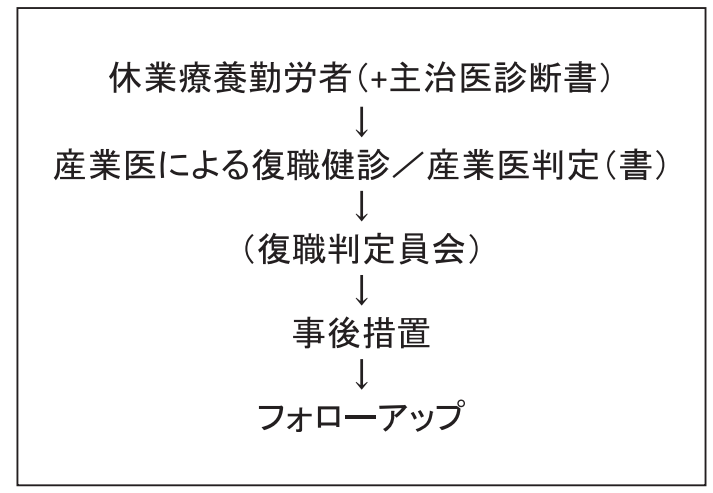

図 4 復職健診システム

\section{適正配置の視点}

産業保健に扔ける復職とは「治療や休養の効果を妨 げず，再発を防止するための復帰についての適正な処 理であり，しかも生産機能に直接参加し得る健康状態 を維持させるもの」と定義されている．具体的には， 産業医の管理下にある長期休業療養勤労者に対して, 適正配置の観点から, 復職健診を行い復職指導, 就業 制限の措置を実施することである。産業医の立場から は, 復職は健康管理活動の 1 つであり, 疾病管理と復 職健診を実施することである.

適正配置とは, 勤労者本人の就業能力と作業負担の バランスをとり，かつ，本人および他者へのリスクを 回避することである（図 3)。前者は就業能力や職場 での「パフォーマンス」の側面であり，後者は自身や 周囲への悪影響などの「リスク」に関する側面であ る.パフォーマンスおよびリスクは適正配置における 職務適正の 2 軸である ${ }^{6}$. このような活動は法的には 上述したように,「労衝安全衛生法」に定める「病者 の就業禁止」を拠り所としている。このリスク管理を 主とした考え方は，リハにおける障害者の社会復州の 促進（復職）を進めていく途中で衝突することがあ る.

例えば，電車機関士が脳卒中罹患後リハを経てごく 軽度の障害のみ残し，運転技能には全く問題ないと判 断されたとしても，再発などの「リスク」から自身お よび第三者（乗客）の安全が優先され，配置転換を余 儀なくされたケースがある ${ }^{3)}$. 障害者の復職に際して は，本人のパフォーマンスのみならず，この点にも配 慮が必要である。 
いという現状がある。この点を踏まえ, 産業保健の現 場におけるわが国の中途障害者の復職の問題点は, (1) 新規雇用が中心の法制度で，中途障害者が法的支援を 受けにくい（民事不介入），(2) 企業毎に異なる複雑な 人事・従業員管理システム, (3) 産業医(企業)一主治 医 (病院) 間の意見の相違の 3 点にまとめることができ よう。

このような問題点を打開するには，企業内にとどま らず，傷病の発症〜復帰後まで連続的にサポートでき る復職支援コーディネーターなどの存在が今後必要で あると考えられる7). 公的な制度として第三者機関内 に所属するコーディネーターが望ましいが，当面は企 業内の産業保健師や, 企業外であれば病院のメディカ ルソーシャルワーカーがその役割を代替できるのでは ないだろうか。また，復職（支援）プログラムが，復 職までの期間の短縮・企業内に打ける休業日数を減少 させるとの報告がある ${ }^{8)}$.今日，メンタルヘルス領域 での復職支援プログラムが発展しているが，身体障害 等への標準的なプログラムは提示されていない.さら に，障害者の復職を支援するためには，医療・福祉側 と受け入れ企業側の考え方を互いに理解し，良好なコ ミュニケーションを保持できる関係を構築することが 重要である.

\section{おわりに}

本シンポジウムでは，中途障害者の復職には企業毎 に異なる複雑な人事・復職システムが影響しているこ
と，産業保健分野は適正配置の視点で復職を捉え，就 労能力とリスクとのバランスを考えていること，企業 内復職システムへの企業外からのアプローチが難しい ことから，復職支援コーディネーター制度の導入やよ り一層の連携が重要であることを述べた.

\section{文献}

1) Saeki $S$, Toyonaga $T$ : Determinants for early return to work after first stroke in Japan. J Rehabil Med 2010 ; 42 : 254-258

2) 佐伯 覚, 水江優子, 稗田 寛, 緒方 甫, 蜂須賀研二, 大久保利晃 : 産業医活動と職場復帰. 日本職業・災害医 学会会誌 $1996 ; 44: 202-206$

3）佐伯 覚: 印象に残ったリハビリテーション事例「今 さら仕事はかえられん!」一復職へのアプローチ一. 総合リハビリテーション $2008 ; 36: 1114-1116$

4）佐伯 覚, 緒方 甫 : 障害者の社会復帰・職業復帰. 臨 床と研究 $1996 ; 73: 1342-1345$

5) Saeki S : Disability management after stroke : its medical aspects for workplace accommodation. Disabil and Rehabil $2000 ; 22: 578-582$

6）立石清一郎: 産業医の立場からの就労支援, 症例に見る 脳卒中の復職支援とリハシステム (豊永敏宏 編). 独立 行政法人労働者健康福祉機構, 神奈川, 2011; pp 94-97

7）豊田章宏, 深川明世, 廣瀬陽子, 鈴木久美子, 郡司康子, 今関早苗 : 平成 22 年度厚生労働省委託事業「治療と職 業生活の両立等の支援手法の開発一式 (脳 - 心疾患)」 の中間報告. 日本職業・災害医学会会誌 $2011 ; 59: 169$ 178

8) Saeki S, Hachisuka K : Medical fitness to return to work for disabled workers. J UOEH $2004 ; 26$ : 41-50 


\title{
障害者の自立支援*1
}

\author{
生方克之*2
}

\section{Supported Independence for Persons with Disabilities*1}

\author{
Katsuyuki UbUKATA*2
}

\begin{abstract}
To support the independence of people with disabilities, especially spinal cord injuries and/or brain injuries, comprehensive rehabilitation that includes vocational and social rehabilitation is necessary to meet individual needs. (Jpn J Rehabil Med 2013; $50: 25^{-30}$ )
\end{abstract}

Key words : 自立支援（supported independence）, 総合リハビリテーション（total rehabilitation）, 障害者福祉（welfare for the disabled）

\section{はじめに}

社会参加を家庭・地域・職場などを構成する人や社 会制度などのシステムとの相互的な関係が存在する空 間で生活をすることとした場合，自立支援は，障害が ある本人の価值観や歴史及び状態を踏まえながら，同 性・同世代の人たちと同様に本人が日々の営みから生 活スタイルなど自身に関することを選択・判断しやす くするための取組みである，学齢期や稼働年齢層の脳 損傷や脊髄障害などによる中途障害者が，復学や復職 など社会生活の中で自立していくためには，個人のプ ラス面に焦点を当てた総合リハビリテーションが自立 支援の重要な要素となる.

1. 障害者の自立支援と社会的状況

1）社会保険分野のリハビリテーション

リハビリテーション（以下，リハ）は 1981 年障害 者インターナショナル（DPI）の定義で「時間を限定 したプロセス」とされている.

回復期リハ病棟の増加と介護保険資源の増加によ り，中途障害者が身体機能を中心にした医学的リ八を
身近な地域で受けられる環境は整備されつつある。し かし，医療及び介護保険という社会保険制度を基盤に したリハ資源の増加は，リハが身体機能訓練として提 供され，「内容と時間を限定したプログラム」の枠組 みになる傾向を強めている.

社会保険制度で行われる身体系のリハは，身体機能 訓練の提供により報酬が得られるため，リハが機能障 害の改善や日常生活動作（ADL）向上を内容とした訓 練が中心になることはやむを得ない。

脳損傷者や脊髄障害者が入院期間中の機能訓練中心 のリハのみで生活スタイルや人生の再設計を含む社会 参加や自立という目標に到達することは難しい例が多 い，そのため，障害者の自立支援のためのリハは，回 復期リハ病棟や介護保険のリハサービスだけでは不十 分な場合がある。

自立支援のリハでは，身体機能的アプローチにより 得られた成果をどのように選択肢の拡大につなげられ るか, 社会生活力（Social Functioning Ability）をど のように高めていくか, 職業的な社会参加や就労の継 続性をどのように図れるか, 生活や人生の再構築にリ

2012 年 9 月 9 日受稿

*1 第 49 回日本リハビリテーション医学会学術集会シンポジウム「障害者の社会参加と職場復帰」(2012 年 5 月 31 日, 福岡）の講演をまとめたものである。

*2 神奈川リハビリテーション病院医療福祉総合相談室/テ 243-0121 神奈川県厚木市七沢 516

Kanagawa Rehabilitation Hospital

E-mail : chiiki-reha@kanagawa-rehab.or.jp 


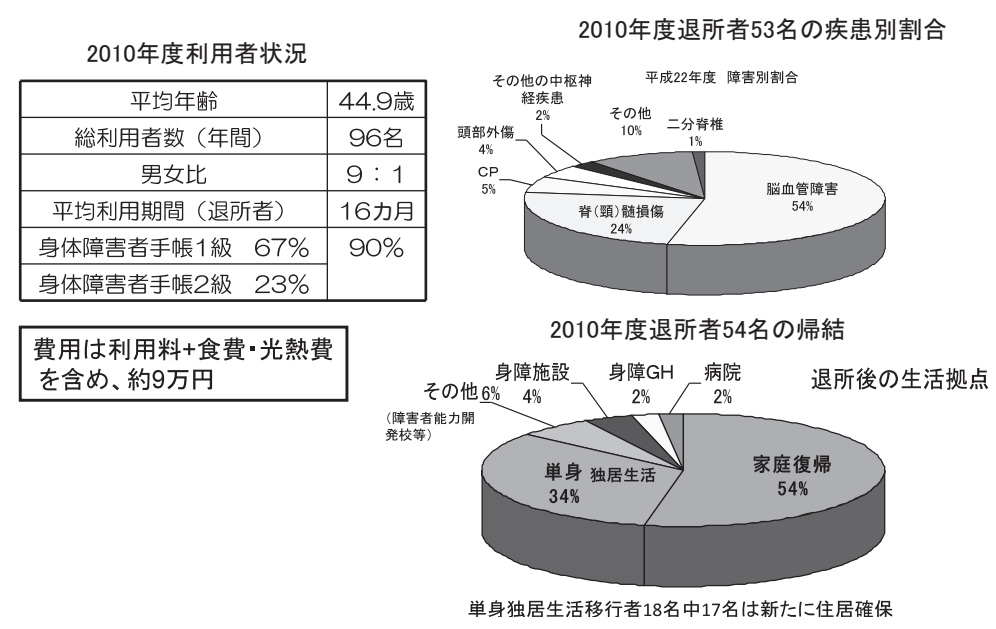

図 1 七沢更生ライトホーム（肢体部門 入所定員 58 名） (七沢更生ライトホーム 平山弘幸作成に加筆)

八をどのように活用できるかという視点が必要であ る。このような視点からのリハには，障害福祉分野の リハを含めた総合リハが必要になるが，障害福祉分野 のリハ機能は全国的傾向として脆弱化してきている.

\section{2）障害福祉分野のリハ}

障害者自立支援法に基づく障害者自立支援施設（旧 身体障害者更生施設）である神奈川県総合リハセン ター内七沢更生ライトホーム（以下，更生ライトホー ム）を例に障害者福祉分野のリ八支援を紹介する．更 生ライトホームの利用者の多くは，入院回復期リ八後 に移行している.

更生ライトホームではニーズを踏まえ機能障害への アプロ一チや社会生活力へのアプローチなど，できる こと・選択し決めることの幅が広がることを目指した リ八を提供している．更生ライトホームのリハ支援内 容は，身体機能訓練，社会リハとして買い物・交通機 関利用・調理・グループ学習・自動車免許取得, 単身 生活実習，職業リハとして作業耐性の向上や就労（復 職）支援などである．社会参加の移行段階では，地域 支援者とのサービス調整や職場調整などが行われる.

脳損傷や脊髄障害などの人たちは身体・認知（高次 脳機能）面の機能障害により健常時の対処法のままで は，「できなくなった体験」を実生活の中で重ねるこ とにより受動的な状態になることが多い，それにより 日常的な行為から生活設計・人生展望など活動から参 加に至る事柄について本人が選択し決めることが健常 時に比べ難しい状況となりやすい。
そのため，障害がある状態となった後にできる部分 に焦点を当て可能性（単に ADL や機器の操作ではな 〈主体的な選択や決定を含む）を体験・実感できるこ と，併せて選択する状況や機会を提供することが中途 障害者の自立支援では重要となる。このように障害福 祉分野のリハは，社会参加や自立支援のための総合リ 八の役割を担っている。

図 1 のように回復期リハ医療の後に更生ライトホー ムの支援を受け，地域で新たに自立生活をする人たち は多い，復職や新規就労者では，就労の土台となる身 体的な耐性や健康・生活管理や通勤方法の獲得 - 介助 者活用などの社会生活力を高める支援を提供してい る.このような支援を通じて本人が健常時と現在の状 況に向き合い折り合いを図りながら個々人にとって新 たな人生や生活へと進んでいる。

しかし，障害者自立支援法ではリ八を生活訓練と機 能訓練に分け別々にサービス給付を行う制度設計に なっている．中途障害者の自立支援ニーズを心身機 能・活動・参加，それに本人や環境因子の相互作用性 を踏まえた生活機能モデルから捉えず，身体訓練と生 活訓練に分けているため，障害福祉分野において自立 支援の観点から総合的なリ八を提供することが難しい サービス体系になっている。

また，障害者手帳の取得可能時期の課題があり，回 復期リハから連続して障害者自立支援法の訓練給付を 必要とする人がサービスにつながりにくい問題や，生 計中心者が中途障害になった場合には前年度所得によ 


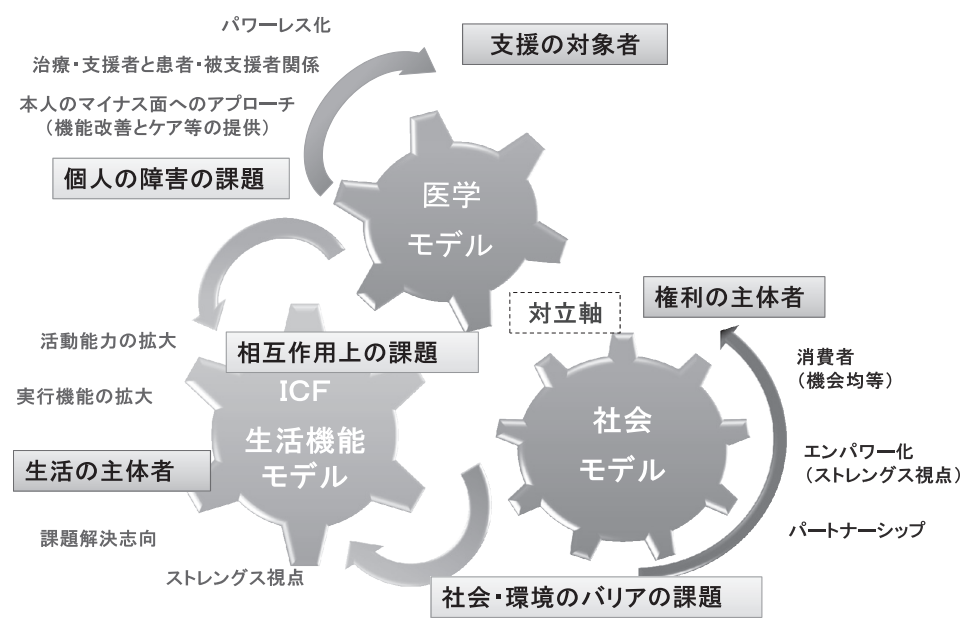

図 23 つの障害モデル

り利用費負担額が決まるため傷病手当金受給者などで は，利用費負担から利用を諦める例がある。

\section{3）障害福祉分野の社会的状況 ${ }^{1 \sim 5}$}

障害福祉分野ではノーマライゼーションやインク ルージョンなどの障害福祉理念や自立生活思想，それ に障害モデル概念などが障害福祉施策つくりに影響を 与えている。

1970 年代にアメリカのエド・ロバーツ（Edward V. Roberts）らにより始められた自立生活運動（Independent living）では，「人の助けをかりて 15 分で衣服を 着，仕事に出かけられる障害者は，自分で衣服を着る のに 2 時間かかるため家にいるほかはない障害者より 自立している」 とい) という自立生活概念を示した。自立 生活運動はリハや障害福祉分野に ADLから生活の質 (QOL), 医学モデルから生活モデルというパラダイ ムシフトをもたらした。

障害福祉分野では，個人の障害の軽減や代償方法の 獲得などを課題と捉える医学モデル，障害がある個人 と背景因子（個人・環境）の相互作用の中で課題を捉 える生活モデル，社会の障壁が課題であると捉える社 会モデルなどの複数の障害モデル概念がある（図 2 ）. 障害モデルの枠組みの曖昧さや個別支援と施策レベル 上の概念整理などが煮詰められていない感はあるもの の，障害福祉分野では社会モデルが主流になりつつあ る。

社会的背景として，障害者の権利条約を国内法に反 映させるためには，障害を社会モデルから捉える必要
性があり，2011年の障害者基本法改正においても障 害を社会モデルから捉えることを明文化すべきという 意見が出されている.

社会モデルの視点からは，リハは障害を個人の課題 として捉える医学モデル・生活モデルとして捉えら れ，社会モデルとの対立軸に置かれる傾向がある。そ のため，障害者福祉施策レベルにおいてリハは存在感 を示しにくい状況にある.

社会モデルを基調にした 2011 年 8 月の障害者福祉 制度改革推進会議総合福祉部会の提言で示されたサー ビス体系には，現在の障害者自立支援法のリハサービ スである訓練給付は明示されていない。

リハの現場で個別支援に従事している者の視点から は，健常状態を基準にしたニーズからスタートしやす い中途障害者の社会参加・自立支援では，本人のニー ズと主体性を重視しながら医学モデルや生活モデル的 なリハアプローチが必要であると考える，障害の社会 モデル概念が障害福祉分野を含む個人への総合リハの 存否に影響を与え過ぎないことを願う状況である.

\section{2. 自立支援の実際}

\section{1) 高位頚髄損傷者の事例 ${ }^{7}$}

高位頚髄損傷者である A さんの例を通じて，障害 者の自立支援とリハの役割について考えてみたい。

$\mathrm{A}$ さんは, 大学 2 年時にバイクの自損事故により頝 髄の $4 \sim 5$ レベルの完全四肢麻痺となり，神奈川リハ 病院を経て復学した。卒業後はアパートで独居生活を しながら特例子会社に採用され在宅就労をしている。 


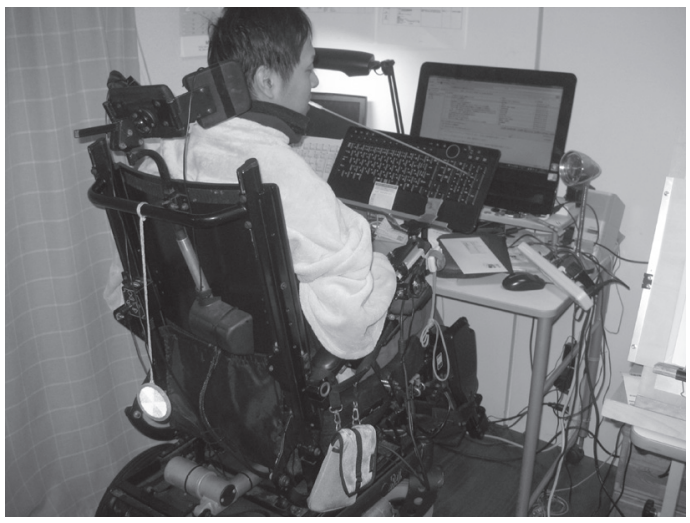

図 3 在宅就労中の A さん：マウススティックで キーボード操作

$\mathrm{A}$ さんは，重度の起立性低血圧があり，海外製のチ ルト・リクライニング機能の電動車椅子を使用し, 頭 部で操作ができるようにへッドサポーターにチルト・ リクライニング操作スイッチを取り付けて，10 分間 に数度チルト機能を使用している．また，電動車椅子 に 1 日 15 時間ほど乗車しているため, コントロール ボックスの操作部やアームサポーターを改造し携帯電 話ホルダーなどを取り付け，マウススティックで携帯 電話の操作などを行っている（図 3).

$\mathrm{A}$ さんは，入院リハの期間に電動車いすにより移動 が自立できることを経験し，大学生活にあわせ介助を 効率的に集約する方法を学び復学した．復学後は実行
的な体力や友人との外出など電動車椅子を使用しての 社会的経験を重ねた。実生活を通じて「できることを 実感」し，同年齢の学生と過ごす環境の中で，障害と いう特徵があっても，受傷前から A さんが抱いてい た卒業後は親から独立し働くという進路を選択した。

$\mathrm{A}$ さんの例では，入院当初よりリハスタッフが復学 という支援目標を持ち，実現のために電動車椅子で長 時間過ごせるための対応や，パソコンや介護・生活関 連機器の操作のための自助具の設定など活動の自由度 を上げるための取り組みを行った。

$\mathrm{A}$ さんの自立生活へのプロセスでは, (1)復学とい う当面の目標に向けて電動車椅子による移動やパソコ ン操作などの活動能力（Capacity）の獲得，(2)「でき ることの体験と実感」「選択肢の拡大」のためのリハ 支援, (3) 復学や就労により広がる社会生活活動の中 での自己決定機会の拡大とその実行 (Performance), (4) 新たな身体状況と社会との関係を通じた主体者と してのアイデンティティーの構築，などが受傷から自 立生活に至る重要な要素になっていると思われる.

図 4 のようにAさんの暮らしは，障害者福祉の思 想から日常的な介助サービス制度などの社会的諸要素 の社会システム，それに社会的諸要素と $\mathrm{A}$ さん個人 との力動的な相互作用の中で，できることの経験を重 ね消費者（主体者）として自立しながら，受傷以前よ り抱いていた生活スタイルを実践している状況であ る.

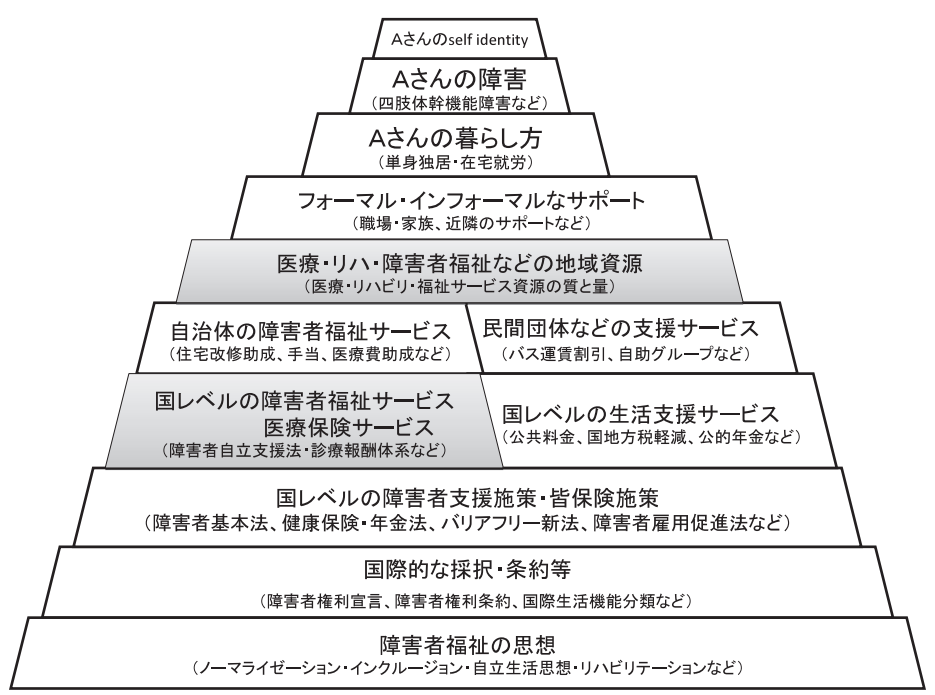

図 4 A さんの暮らしを支える社会システム（文献 7 より用） 
リハは $\mathrm{A}$ さんの自立生活を支える社会的構成要素 （環境因子）の 1 つである.

2）自立支援のためのリハサービス

$\mathrm{A}$ さんの事例からも障害者の自立のためのリハは, 目的の行為を達成する方策や選択肢を増やし, 本人が 主体となり判断する機会を増やす取り組みである.

中途障害者では，できない体験を新たに経験するこ とによりディスエンパワー状態に陥やすい，前記した ように病院で身体機能訓練中心の回復期リ八医療を受 け，家庭復帰した後に社会生活活動を通じて活動や参
加の困難さを実感し，自信の喪失や主体性の抑制など 二次的な制限を受ける人たちは数多い。このような場 合には，本来，社会参加や自立支援を目標として取り 組むべき障害者支援の課題が，身体機能訓練の継続や 介護サービスの提供の課題へと転換し，いっそう本人 の主体性が失われる危険性がある。

社会保険制度に基づくリハ資源は増加しても，回復 期リハ医療後に中途障害者の自立支援や具体的な職場 復帰支援を担うリハ資源は全国的にみても限られてい る.
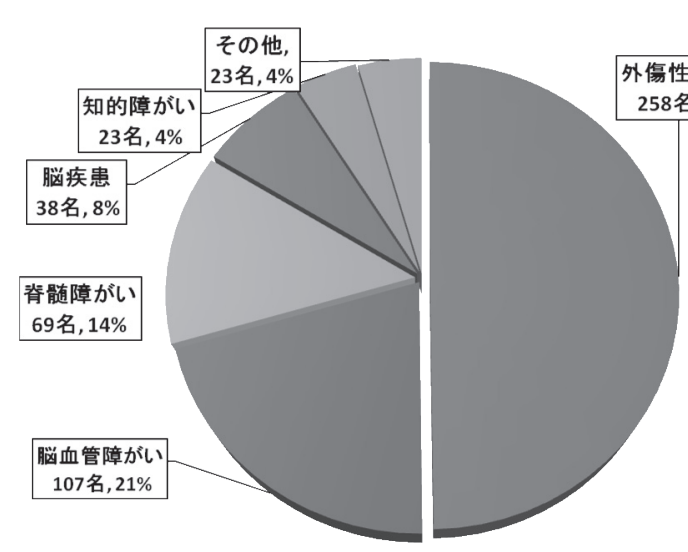

2011年度利用者の障害(518名)

病院外来 279 名, $54 \%$
身障自立支援施設 13 名 $3 \%$ 知的自立支援施設 23 名 $4 \%$

\begin{tabular}{|c|c|c|c|}
\hline \multicolumn{4}{|c|}{ 2011年度の就職者数 } \\
\hline \multirow{6}{*}{ 新規就労 } & \multirow{6}{*}{ 15名 } & 外傷性脳損傷 & 8名 \\
\hline & & 脳血管障害 & 2名 \\
\hline & & 脊髄障害 & 1名 \\
\hline & & 脳疾患 & 1名 \\
\hline & & 知的障害 & 2名 \\
\hline & & その他 & 1名 \\
\hline \multirow{5}{*}{ 復職 } & \multirow{5}{*}{ 33名 } & 外傷性脳損傷 & 15名 \\
\hline & & 脸血管障害 & 11名 \\
\hline & & 脊髄障害 & 4名 \\
\hline & & 脳疾患 & 2名 \\
\hline & & その他 & 1名 \\
\hline \multirow{5}{*}{ 自営 } & \multirow{5}{*}{ 4名 } & 外傷性脳損傷 & 1名 \\
\hline & & 脳血管障害 & 1名 \\
\hline & & 脊髄障害 & 1名 \\
\hline & & 脳疾患 & 1名 \\
\hline & & その他 & \\
\hline & \multicolumn{3}{|c|}{ 52名 (42名が高次脳) } \\
\hline
\end{tabular}

図 5 神奈川リハ病院職能科の支援状況：2011 年度利用者と就職者数 (神奈川リハビリテーション病院職能科作成)

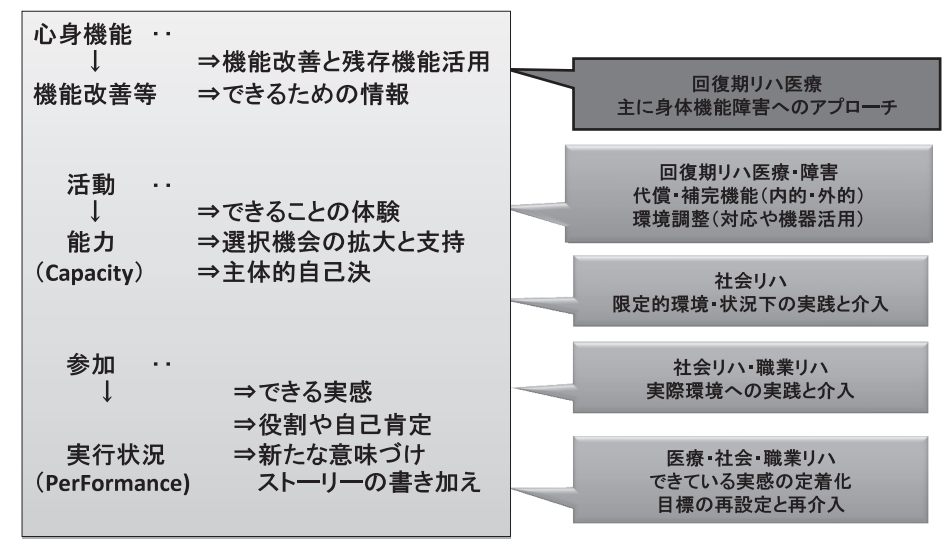

図 6 中途障害者の自立支援のためのリハプロセス（高次脳機能障害者 や中途重度身体障害者など） 
そのため，中途障害者の自立支援では，入院による 回復期リ八医療期間後に機能障害や活動制限への医学 リハや社会リハ・職業リ八を備えた障害者福祉サービ ス分野による総合的なリハサービスが提供されること が望ましい。

神奈川リハ病院では，更生ライトホーム以外に病院 部門に職能科があり，職業リハを提供している。主な 利用者は，本人の障害認識などの状態から障害福祉 サービスにすぐにつながらない人や，障害者手帳の取 得可能時期の課題などから障害者福祉サービスにつな がりにくい人たち，他には地域の通所系施設の利用と 並行して職業リ八支援が必要な人たちである。職能科 の利用者および支援州結は図 5 のようになる。当院の 職能科は診療報酬上の裏付けのないサービスである が，支援がなければ就労が困難なレベルの高次脳機能 障害者や重度四肢麻痺者などの利用者が多い特徵があ る.

図 6 に示すような中途障害者の自立支援のリハの視 点から神奈川県総合リハセンターではリハサービスを 提供している.

\section{おわりに}

社会保険制度による機能訓練を中心にしたリハを身 近な地域で受けるための環境は整備されてきている. 一方，脳損傷や脊髄障害などによる中途障害者の社会 参加や自立を目標にしたリ八支援は，急性期後の回復 期リ八医療期間のみでは難しい場合があり，障害福祉
分野のリハ機能が必要である.

障害福祉分野では，障害を社会との関係性で捉える 社会モデル概念が主流になる中で個別の自立支援ニー ズに対応する総合リハの提供が難しくなりつつある.

障害者の自立支援のためのリ八を推進するために は，リ八医療従事者が国際生活機能分類 (ICF) の障 害概念である障害を個人と環境との相互作用上の課題 として捉え，リハは本人の選択肢の拡大，及び主体的 な活動（消費や生産）への支援を担う促進的な環境因 子である意識を持つことが必要である．併せて，社会 保険分野のリハ関係者は総合リハの実践のフィールド となりやすい障害福祉分野のリハを身近な地域で提供 されることを求める社会活動を行うことが必要である。

\section{文献}

1）樋口恵子：日本に扔ける自立生活運動.リハビリテー ション研究 $1992 ; 71: 32-33$

2) 石川 准, 長瀬 修: 障害学への招待. 明石書店, 東京, 1999

3）石尾絵美: 障害の社会モデルの理論と実践. 技術マネジ メント研究 $2008 ; 7: 37-39$

4）障がい者制度甲斐化幾推進会議総合福祉部会 : 障害者 総合福祉法の骨格に関する総合福祉部会の提言. 東京 都社会福祉協議会複製, 2011

5）第 34 回総合リハビリテーション研究大会抄録集 2011

6）定藤丈弘：アメリカにおける障害者の自立生活運動と 課題.ノーマライゼーション 障害者の福祉 $1997 ; 17$ ： $41-45$

7）生方克之: 障害者の自立支援. 総合リハビリテーション 2012 ; 40 : 807-815 
職業リハビリテーションの概念と支援モデル*1

\author{
松為信雄 $* 2$
}

\title{
The Concept of Vocational Rehabilitation and a Practical Supporting Model*1
}

\author{
Nobuo Matsui $* 2$
}

\begin{abstract}
Vocational rehabilitation activities are interdisciplinary, so the concept is always reviewed according to academic development. In this paper I suggest a new definition of vocational rehabilitation and a practical supporting model, grounded on 5 keywords (vocation, rehabilitation, counseling, career and ICF). (Jpn J Rehabil Med $2013 ; 50: 31-35)$
\end{abstract}

Key words : 働くこと (work), リハビリテーション (rehabilitation), カウンセリング (counseling)，キャリア (career), 国際生活機能分類（ICF）

はじめに

職業リハビリテーション（以下，職業リハ）の実際 の活動には，さまざまな学際的な分野の知識や援助・ 介入の技術が導入されていることから，職業リ八の概 念を明らかにするには，核となるキーワードに基づい て検討することが効果的であろう。

職業リハは Vocational Counseling もしくは Rehabilitation Counseling の和訳である。それゆえ，その概 念には，基本的には「職業もしくは働くこと（Vocation)」「リハ (Rehabilitation)」「カウンセリング (Counseling)」の意味を包括していなければならな い.さらに，これらのキーワードに加えて，活動の対 象となる人を捉えるには「障害構造」の概念を取り达 むことが必須だろう。また，ここで言う「カウンセリ ング」は「キャリアカウンセリング」の視点に即して いることから，「キャリア」の概念も不可欠であ $る^{1,2)}$.

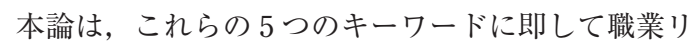
八の概念との関連を明らかにするとともに，それを踏
まえた定義と活動モデルについても言及する.

\section{理論を構成する概念}

\section{1. 働くことの意義}

働くことの意味は, 社会的な視点と個人的な視点, の 2 つ側面から捉えることが必要である．前者は, 社会の存続や発展に必要な生産的な活動が分割されて 個人に割り当てられたもの，とみなしている．割り当 てられた役割を継続的に従事することによって，貨金 などの報酬が分配されるのである。これに対して後者 は，そうした役割を果たすことを通して，自分の能力 や興味を発揮し心理的な満足を得る源泉となることに 焦点を当てる．仲間を作り，先輩や後輩に自分の存在 を認めてもらい, 自分自身の達成感や満足感を得ると いった機会がもたらされる3.

生物・心理・社会的な障害のある個人にすれば，働 くことは, (1) 生活リズムの調整や体力・健康の維持 につながり，(2)心理的な満足や自尊心が獲得でき， (3)生計を維持するための経済的な基盤が提供され, (4)人間関係の確立や人格形成などの社会的な関わり

2012 年 9 月 7 日受稿

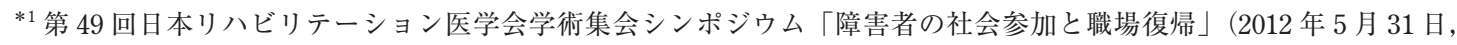
福岡）の講演をまとめたものである.

*2 神奈川県立保健福祉大学/ $\% 238-8522$ 神奈川県横須賀市平成町 1-10-1

Kanagawa University of Human Services

E-mail : matsui-n@kuhs.ac.jp 
を持てる場となる。こうした多面的な意義があるがゆ えに，たとえ障害があろうと働くことの意義は大きい のである。

その意味で，正規就業時間での就業のほかに，短時 間就労やグループ就労あるいは在宅就労などの多様な 働きかたの開発や，障害者自立支援法の施行による移 行支援事業型や就労支援継続型などの施設事業の展開 は，障害のある人の働く場を拡充する施策であり，働 くことを通した社会参加の可能性を広げていくことに なる。

\section{2. リハのあり方}

リハに関する定義はいくつかあるが，障害者イン ターナショナルが 1981 年に提示した「身体的・精神 的・社会的に最も適した機能水準の達成を可能にする ことで，各個人が自らの人生を変革して行く手段の提 供を目指し，かつ時間を限定したプロセスを意味す る」は，最もよく引用されるものである ${ }^{3)}$.

この定義には，以下の 4 つの重要な概念が含まれて いる. 第 1 は「身体的・精神的・社会的に」とあるよ うに，リハは医学分野に限るものではなく，教育や社 会的分野に加えて職業的な分野も重要な構成要因であ り，いわゆる総合リ八の視点に立つことが不可欠であ ることを意味する．第 2 は「最も適した機能水準の達 成」にあるとおり，リ八活動は，個人の置かれている さまざまな環境（職業や職場なども当然この中に含ま れる）との間で「最適な機能水準」となる関係性を目 指すものであり，発症以前の状態にまで回復させる 「最高の状態」を求める訳ではない，第 3 は「各個人 が自らの人生を変革して行く」とあるように，対象者 本人の意思決定や自主性さらにはそのためのエンパ ワーメントの向上を重視する。そして，第 4 に「時間 を限定したプロセス」とあるように，実行プログラム には始まりと終わりがあるがゆえに，実施に際しては ケースマネジメントの視点が不可欠であることを示唆 している.

この最後にある「時間を限定したプロセス」とは， プログラム終了時の評価を踏まえて，必要に応じて新 たなプログラムを展開することを意味する，それは言 い換えると，人生行路において，竹の節を継ぐように 時系列的に実施プログラムが継続されて行くことを示 唆する.「生活の質 $(\mathrm{QOL}) 」 の$ 向上は，そうしたプ ログラムの繋がりの過程をとおして獲得されることに なろう。

\section{3. カウンセリング}

リハカウンセリングは，我が国では，その領域や内 容について幅広く認知されているとは言い難い。心理 療法としてのカウンセリングや産業カウンセリングと も異なり，リハカウンセリングの独自性は，後述する 機能障害・活動制限・参加制約などの影響を最小限に 留めて，それらが社会参加に及ぼす影響を可能な限り 阻止するための多様な活動を展開する支援技術にあ る、そのための実際の活動は，支援や介入の対象を誰 に（あるいは何に）向けるかによって異なる ${ }^{3)}$.

第 1 に，支援の対象が障害のある本人に向けられる 場合には，障害によって否定的になった自己像を現実 の場面に即して肯定的に再統合化したり，達成が困難 となった将来目標を現実に即して達成可能な目標とし て再構築するための「カウンセリング」が必要であ る。第 2 に，障害によって機能低下した職務遂行の技 能や能力を回復・復旧させたり，代替えの技能を再学 習して仕事や職場の求める諸能力と調整するための 「コーディネート」が求められている。第 3 に, 家族, 学習環境, 同僚集団, 自立生活環境, 仕事環境, 文 化・政治・経済的状況などのさまざまな環境要件に対 して支援や介入をする場合には，対象者本人の現有す る諸能力でも対応できるようにそれらの環境要件その ものを再構造化することが必要となろう。そのために は「コンサルテーション」が必要である，第 4 に，実 際の支援を提供する専門家や非専門の人たちに対して は，提供される支援内容が対象者本人のニーズに応え 得るように調整する「ケースマネジメント」が必要と なろう，と同時に，実施プログラムの成果を評価する ことも不可欠である ${ }^{3}$.

職業リハの実践技術では，リハカウンセリングにお けるこれらの支援・介入の基本的な視点を広範に取り 込むことが不可欠である.

\section{4. キャリア}

キャリアという用語にはさまざまな意味があるが, 基本的には，職業経歴や仕事そのものを意味する 「ワークキャリア」と，職業生活を含むさまざまな生 活場面で個人が果たす役割をふまえた働き方や生き方 を指す「ライフキャリア」に分けてとらえることがで きる。また，ライフステージの語よりも，個人が主体 的に役割を選択してその遂行に意図的・積極的に関わ ることが強調される ${ }^{4}$.

特に，ライフキャリアに即して個人の発達的な変化 
を考える場合，人はその生涯を通して，子供・学生・ 余暇人・市民・職業人・家庭人などの多様な役割を遂 行することに着目する．発達過程でこれらの多様な役 割にどのような主体的な関わり方をしたかによってそ の人のライフスタイルが構成され，その生涯にわたる 全体的な構造によって人生経歴のパターンが定まるか らである。誕生から学齢期を経ながらその後の就職や 職業生活の参入と維持そして退職後の人生に至るま で，その生涯にわたる個人の働き方や生き方について 考えることになる。「生活の質」は，そうした多様な 役割のどれに自己の価值を見出し，実際に行動として 参加し感情的な思い入れをするかの程度によって決ま ることだろう。

生物・心理・社会的な障害のある人を対象にした, その生涯に及ぶキャリア発達の過程を見据えたライフ キャリアに関する支援や，その職業経歴や職場定着あ るいは広範な雇用管理に関する知見などについては, さらなる学問的あるいは実践的な蓄積が求められてい る。また, 職業リハの活動は, 家庭・学校・職場・地 域社会などの多様な社会集団からの要請を充足すると ともに，それらのニーズを視野に入れつつ，職業人と しての役割遂行を通して自己の価值観や意志を満足さ せてゆく活動であるという認識が大切になろう。

\section{5. 障害の構造}

世界保健機関（WHO）が 2001 年に提示した「国際 生活機能分類 (ICF)」は, 人間の生活全体の機能 (「生活機能」) を包括的に把握して, その多かれ少な かれ否定的な側面を「障害」と見なすものである。こ のモデルは, 1980 年の「国際障害分類 (ICIDH)」に ある「能力障害」や「社会的不利」の代りに「活動」 と「参加」の語を用いることで障害のある個人が主体 的に立ち向かう側面を強調し，また，「個人因子」と 「環境因子」などの背景因子が「活動」や「参加」を 制限することを明確にした。

こうした障害構造からすると, 職業リハが対象とす るのは,「国際障害分類 (ICIDH)」に従えば「社会的 不利」であり，「国際生活機能分類（ICF）」に従えば 「個人因子」や「環境因子」などの背景因子で規定さ れる可能性の高い「活動の制限」ということになろ う.

職業リハの対象となる障害を，こうした環境との相 互作用によって生じると規定することによって，この 分野に打ける実際的な支援技術は，生物・心理・社会
的な障害のある個人とそうした個人を取り巻く種々の 環境要件との相互関係のあり方の改善に焦点が当たる ことになる。そのための実際の手法としては，個人に 焦点を当てて, その諸能力や技能を習熟させたり働く ことへの意識付けや動機付けなどを向上させて, 環境 との適合性を高めるための種々の支援技法が必要であ る. と同時に, 労働市場や一般企業などの職場あるい は福祉的就労の場などのさまざまな環境に焦点を当て て, 個人の能力や特性に応じてそれらの環境要件を変 えるためのさまざまな支援技法も必要となろう。職業 リハの実践的な技術体系には，こうした障害のある個 人に向けられた支援と産業・職業・職場などの環境要 件に向けられた介入や調整，の双方に関わる具体的な 方法を取り込んで構成されていなければならない33.

\section{支援モデルと定義}

\section{1. 支援モデル}

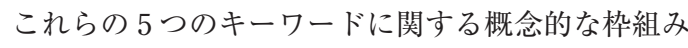
を踏まえて, 職業リハの実際的な活動の支援モデルを 描いたのが図である ${ }^{3)}$.

図に示すニーズは，個人の側で生じるものと集団 (環境) の側で生じるものがあり，そのいずれも重要 である．個人のニーズを捉えるキーワードは，「生理 的欲求」「安全欲求」「所属欲求」「自尊欲求」「自己実 現欲求」の 5 段階の欲求構造をなすものとして示して いる.これに対して, 集団（環境）のニーズとは集団 が存続するために必要不可欠な要件をいう。それは集 団（環境）をどのように分類するかによって異なる が, ここでは, 職場や地域や家庭などの集団の違いと して示した.

個人と集団のニーズは，集団を構成する個人に付与 される「役割」を個人が遂行することを通して獲得さ れる。「役割」の遂行を媒介として，個人は集団の ニーズに応える「充足」を集団に，また，集団は個人 のニーズに応える「満足」を個人に，それぞれもたら すことになる．

この集団には「充足」を個人には「満足」をもたら す実際的な行動が「対処行動」である.対処行動は, 集団のニーズを充足させるための具体的な課題に対し て，個人が積極的にそれに応える活動であり，それに よって個人のニーズもできるだけ満足に至ることが望 ましい，実際には「充足」と「満足」のいずれも 100\%達成するには至らず，双方が妥協できる（最高 


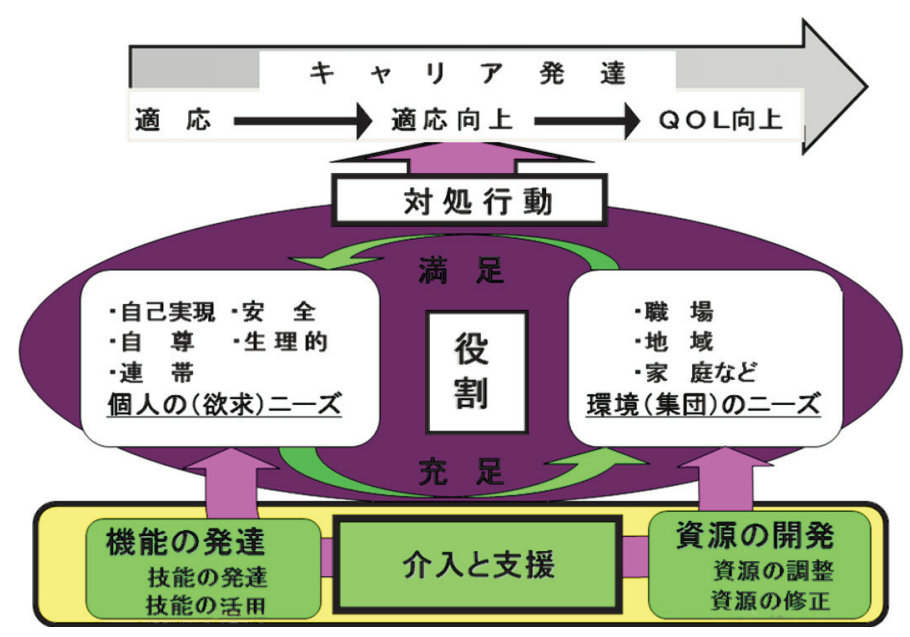

図＼cjkstart職業リハ活動の概念モデル

ではなく）最適の水準に至ればよしとするものであ り，「対処」にはそうした意味が込められている。そ のため，対処の仕方はすべての人で同じである必要は なく, どんな方法であれ, 具体的に要求される課題に 対して結果として応えることができれば良い.

対処行動をとおして，満足と充足の双方を高めてい く過程が「適応」である。それは, 生活体がある特定 の環境のもとでその機能を円滑に維持し続けている状 態である，良い適応状態であるには，個人の行動が環 境や集団のニーズに一方的に応えるのではなくて，そ れを通して，自分のニーズをも満足させていく過程で なければならない. 集団のニーズを充足させるだけで は適応とは言わないのである.

こうした適応の過程は, 役割の違いによって異なる し，短期日に達成できるものではない，また，異なる 環境要件に遭遇するたびに新たな適応に至ることが求 められる，その意味で，適応の向上は生涯にわたって 継続するものであり，そうした過程の全体が「キャリ ア発達」に相当する。「人生の質 (QOL)」の向上は こうしたキャリア発達の過程をとおして得られる.

\section{2. サービスや支援の戦略}

この支援モデルに従えば，職業リハの活動は，集団 と個人が役割の遂行を介して充足と満足が最適の状態 になるように発達の過程を通して支援することで人生 の質の向上を目指す，ということになろう.

そのための実際の支援や介入のあり方は，それゆ え，個人と環境（集団）の双方に向けて提供されねば
ならない。そのことによって，個人ニーズの「満足」 と環境（集団）ニーズの「充足」が，らせん階段を昇 るように向上することになる。この個人の側と環境 （集団）の双方に焦点を当てながら併行して支援や介 入を行う視点こそ, 職業リハに固有の技術体系であろ う.

個人の側に向けられたサービスや支援は「機能の発 達」を促すことを目指す。これはさらに，習得してい ない機能を教育や訓練で新規に獲得させる「技能の発 達」と, 既存の機能を直面する実際の環境場面で活用 できるように再学習する「技能の活用」の 2 つの戦略 がある．他方で，環境や集団の側に向けられたサービ スや支援は「資源の開発」を促すことを目指す。これ もまた，既存の社会資源を選択したり調整しながら活 用する「資源の調整」と, 個人の能力や必要性に応じ て既存の社会資源そのものを改善する「資源の修正」 の 2 つの戦略がある.

こうした，支援や介入にかかる 4 つの戦略を駆使で きるのが，職業リハ活動の特異なところであろう。

\section{3. 定義と視点}

職業リハの定義は，我が国ではほとんど，1983 年 の国際労働機関（ILO）第 159 号条約にある「すべて の障害者が適当な雇用に就き，それを継続し，かつ， それにおいて向上することができるようにすること， 並びに，それにより障害者の社会への統合又は再統合 を促進すること」が引用される．だが，この定義は， 上述のキーワードに関係した概念を必ずしも反映して 
いるとは言えないだろう。このことは，我が国におけ る職業リハの概念や視点, 支援モデルと対象, 評価と 支援方法，支援を担う人材と企業理解，研究機能など のさまざまな側面から概観した結果からも言えよう5).

それゆえ筆者は,「生物・心理・社会的な障害のあ る人が，主体的に選択した仕事役割の継続をとおして 生活の質が向上するように，発達過程の全体を通して 多面的に支援し，それにより社会への統合又は再統合 を促進する総合的な活動」と定義している ${ }^{1)}$.

これは，(1)サービス対象となる個人は「生物・心 理・社会的な障害のある人」とし, 生物 ・心理・社会 的側面が相互に影響しあう障害のある人に加えて, 社 会的側面で課題が突出する機能・形態障害や活動制限 はないが社会参加の制約がある人（たとえば，生活保 護者, 低所得層, 刑余者など) も広義の対象と見なし ている. (2)サービスの目的は「社会への統合又は再統 合の促進」とし, ILO 第 159 号条約を踏襲するととも に，それを発展させて「共生社会」の形成に向けた活 動を目指すことを意味する。 (3)支援の方向は「主体的 に選択した仕事役割の継続」であり，役割遂行を踏ま えた働くことの意義を強調するとともに，それを自分 の意志で主体的に決定すること，また，役割継続のた めの支援は，必然的に個人と職場（それを包括した多 様な環境要件）の双方から向けられることを意味す る。文支援は「発達過程の全体を通して多面的」に活 動するものであり, 職業人としての役割継続は家庭や 地域などの多様な場面での役割遂行と不可分の関係に
あることから, 発達過程の全体を通して役割遂行に対 する支援を一体的に行うことが不可欠あることを意味 する.

\section{おわりに}

職業リハの定義および実際活動の支援モデルを，5 つのキーワードを踏まえて考察してきた，特に，活動 活動を人生全体を見越した発達的な視点すなわちキャ リア発達論から捉えることは, 生活の質の向上をめざ す総合リハの目標にかなうものである.

実際の活動は，支援モデルで示唆するように，個人 の側とそれを取り巻く種々の環境要因の双方に均等に 向けられることが特徵である.

\section{文献}

1）松為信雄: 職業リハビリテーション概念の構築に向け て. 職業リハビリテーション $2008: 21(2):$ 51-55

2) 松為信雄, 朝日雅也, 八重田淳, 小川 浩, 相澤欽一：(座 談会）あらためて職業リハビリテーションの概念を問 う.職業リハビリテーション $2008: 22: 30-47$

3）松為信雄, 菊池恵美子 編 : 職業リハビリテーション学 一改定第 2 版一. 協同医書出版社, 東京, 2006

4）松為信雄: キャリアデザインの意義と職業リハビリ テーション. 職業リハビリテーション $2010: 23(2)$ : 29-32

5）松為信雄: 我が国における職業リハビリテーションの 動向. 障害のある人の就労支援のための職業リハビリ テーションの基礎と実践（日本職業リハビリテーショ ン学会 編). 中央法規出版, 東京, 2012; pp 14-37 